Article

\title{
One-Pot Self-Assembly of Dinuclear, Tetranuclear, and H-Bonding-Directed Polynuclear Cobalt(II), Cobalt(III), and Mixed-Valence Co(II)/Co(III) Complexes of Schiff Base Ligands with Incomplete Double Cubane Core
}

\author{
Santokh S. Tandon ${ }^{1,2, *}$, Neil Patel ${ }^{2}$, Scott D. Bunge ${ }^{2} \mathbb{(}$, Esther C. Wang ${ }^{2}$, Rachel Thompson ${ }^{2}$ \\ and Laurence K. Thompson ${ }^{3}$ \\ 1 Department of Chemistry and Biochemistry, Kent State University - Salem Campus, Salem, OH 44460, USA \\ 2 Department of Chemistry and Biochemistry, Kent State University, Kent, OH 44242, USA; \\ neilnpate189@gmail.com (N.P.); sbunge@kent.edu (S.D.B.); ewang2@kent.edu (E.C.W.); \\ rthoma17@kent.edu (R.T.) \\ 3 Department of Chemistry, Memorial University, St. John's, NL A1B 3X7, Canada; laurie.thomp@gmail.com \\ * Correspondence: standon@kent.edu
}

Received: 17 October 2020; Accepted: 25 November 2020; Published: 28 November 2020

check for updates

\begin{abstract}
The reaction of 2,6-diformyl-4-methylphenol (DFMF) with 1-amino-2-propanol (AP) and tris(hydroxymethyl)aminomethane (THMAM) was investigated in the presence of Cobalt(II) salts, ( $\left.\mathrm{X}=\mathrm{ClO}_{4}^{-}, \mathrm{CH}_{3} \mathrm{CO}_{2}^{-}, \mathrm{Cl}^{-}, \mathrm{NO}_{3}{ }^{-}\right)$, sodium azide $\left(\mathrm{NaN}_{3}\right)$, and triethylamine (TEA). In one pot, the variation in Cobalt(II) salt results in the self-assembly of dinuclear, tetranuclear, and $\mathrm{H}$-bonding-directed polynuclear coordination complexes of Cobalt(III), Cobalt(II), and mixed-valence $\mathrm{Co}^{\mathrm{II}} \mathrm{Co}^{\mathrm{III}}$ : $\left[\mathrm{Co}_{2}{ }^{\mathrm{III}}\left(\mathrm{H}_{2} \mathrm{~L}^{-1}\right)_{2}\left(\mathrm{AP}^{-1}\right)\left(\mathrm{N}_{3}\right)\right]\left(\mathrm{ClO}_{4}\right)_{2}(\mathbf{1}),\left[\mathrm{Co}_{4}\left(\mathrm{H}_{2} \mathrm{~L}^{-1}\right)_{2}\left(\mu_{3}-1,1,1-\mathrm{N}_{3}\right)_{2}\left(\mu-1,1-\mathrm{N}_{3}\right)_{2} \mathrm{Cl}_{2}\left(\mathrm{CH}_{3} \mathrm{OH}\right)_{2}\right] \cdot 4 \mathrm{CH}_{3} \mathrm{OH}$ (2), $\quad\left[\mathrm{Co}_{2}{ }^{\mathrm{II}} \mathrm{Co}_{2}{ }^{\mathrm{III}}\left(\mathrm{HL}^{-2}\right)_{2}\left(\mu-\mathrm{CH}_{3} \mathrm{CO}_{2}\right)_{2}\left(\mu_{3}-\mathrm{OH}\right)_{2}\right]\left(\mathrm{NO}_{3}\right)_{2} \cdot 2 \mathrm{CH}_{3} \mathrm{CH}_{2} \mathrm{OH} \quad(3)$, and $\left[\mathrm{Co}_{2}{ }^{\mathrm{II}} \mathrm{Co}_{2}{ }^{\mathrm{III}}\right.$ $\left.\left(\mathrm{H}_{2} \mathrm{L1}^{2-}\right)_{2}\left(\mathrm{THMAM}^{-1}\right)_{2}\right]\left(\mathrm{NO}_{3}\right)_{4}$ (4). In 1, two cobalt(III) ions are connected via three single atom bridges; two from deprotonated ethanolic oxygen atoms in the side arms of the ligands and one from the1-amino-2-propanol moiety forming a dinuclear unit with a very short (2.5430(11) $\AA$ ) Co-Co intermetallic separation with a coordination number of 7, a rare feature for cobalt(III). In 2, two cobalt(II) ions in a dinuclear unit are bridged through phenoxide $\mathrm{O}$ and $\mu_{3}-1,1,1-\mathrm{N}_{3}$ azido bridges, and the two dinuclear units are interconnected by two $\mu-1,1-\mathrm{N}_{3}$ and two $\mu_{3}-1,1,1-\mathrm{N}_{3}$ azido bridges generating tetranuclear cationic $\left[\mathrm{Co}_{4}\left(\mathrm{H}_{2} \mathrm{~L}^{-1}\right)_{2}\left(\mu_{3}-1,1,1-\mathrm{N}_{3}\right)_{2}\left(\mu-1,1-\mathrm{N}_{3}\right)_{2} \mathrm{Cl}_{2}\left(\mathrm{CH}_{3} \mathrm{OH}\right)_{2}\right]^{2+}$ units with an incomplete double cubane core, which grow into polynuclear 1D-single chains along the $a$-axis through H-bonding. In 3, $\mathrm{HL}^{2-}$ holds mixed-valent $\mathrm{Co}$ (II)/Co(III) ions in a dinuclear unit bridged via phenoxide $\mathrm{O}, \mu-1,3-\mathrm{CH}_{3} \mathrm{CO}_{2}{ }^{-}$, and $\mu_{3}-\mathrm{OH}^{-}$bridges, and the dinuclear units are interconnected through two deprotonated ethanolic $\mathrm{O}$ in the side arms of the ligands and two $\mu_{3}-\mathrm{OH}^{-}$bridges generating cationic tetranuclear $\left[\mathrm{CO}_{2}{ }^{\mathrm{II}} \mathrm{Co}_{2}{ }^{\mathrm{III}}\left(\mathrm{HL}^{-2}\right)_{2}\left(\mu-\mathrm{CH}_{3} \mathrm{CO}_{2}\right)_{2}\left(\mu_{3} \mathrm{OH}\right)_{2}\right]^{2+}$ units with an incomplete double cubane core. In $4, \mathrm{H}_{2} \mathrm{~L}^{-2}$ holds mixed-valent $\mathrm{Co}$ (II)/Co(III) ions in dinuclear units which dimerize through two ethanolic $\mathrm{O}\left(\mu-\mathrm{RO}^{-}\right)$in the side arms of the ligands and two ethanolic $\mathrm{O}\left(\mu_{3}-\mathrm{RO}^{-}\right)$of THMAM bridges producing centrosymmetric cationic tetranuclear $\left[\mathrm{Co}_{2}{ }^{\mathrm{II}} \mathrm{Co}_{2}{ }^{\mathrm{III}}\left(\mathrm{H}_{2} \mathrm{~L}^{-2}\right)_{2}\left(\mathrm{THMAM}^{-1}\right)_{2}\right]^{4+}$ units which grow into 2D-sheets along the $b c$-axis through a network of H-bonding. Bulk magnetization measurements on 2 demonstrate that the magnetic interactions are completely dominated by an overall ferromagnetic coupling occurring between $\mathrm{Co}$ (II) ions.
\end{abstract}


Keywords: self-assembly of Co(II), Co(III); mixed-valence Co(II)/Co(III) complexes of Schiff base ligands; dinuclear; tetranuclear; polynuclear $\mathrm{Co}(\mathrm{II}), \mathrm{Co}(\mathrm{III})$; $\mathrm{Co}(\mathrm{II}) / \mathrm{Co}(\mathrm{III})$ complexes; mixed-valence $\mathrm{Co}(\mathrm{II}) / \mathrm{Co}(\mathrm{III})$ complexes; Cobalt(II)/Cobalt(III) complexes of Schiff base ligands with incomplete double cubane core; H-bonding-directed formation of cobalt supramolecular architectures with1D-single chains and 2D-sheet structures

\section{Introduction}

Using simple building blocks, living organisms use self-assembly processes to fabricate symmetrical biomolecules (proteins, DNA, lipids, enzymes), with varied levels of structural complexities [1-3]. Inspired by nature, during the last few decades, chemists have used self-assembly processes successfully [4-6] to generate a variety of supramolecular architectures (organic materials [7-9], metalacyclic polygons and polyhedral [10], and nanoscale systems [11,12]) with desired size, shape, and function. The self-assembly process often utilizes a variety of cooperative and noncovalent interactions such as hydrogen bonding, strong electrostatic, and van der Walls forces, $\pi-\pi$ stacking, hydrophobic, hydrophilic, and metal-ligand interactions to produce complex supramolecular architectures which are difficult or in some cases impossible to make otherwise. Self-assembly processes have many advantages over the stepwise synthesis of large supramolecular assemblies, and lead to the formation of desired products from the predetermined building blocks spontaneously and more efficiently while minimizing/eliminating the formation of side products. In most of the self-assembly processes, metal ions or hydrogen ions $\left(\mathrm{H}^{+}\right)$are used as a template for producing supramolecular coordination complexes with 1D-, 2D-, and 3D-network structures and grid systems [13-23].

Over the past thirty-five years, we have been interested in the self-assembly of polynuclear coordination complexes of transition metals to get a deeper insight into magneto-structural relationships, to understand the role of metal ions in self-assembly and structural complexities of assemblies produced, and the effects of the anions on the formation and coordination abilities of the macrocyclic and non-cyclic Schiff base ligands. Our interest in this area originated from the implications of transition metal complexes in homogeneous catalysis [24,25], as enzyme models [26-29], and their potential applications in magnetic materials [30-34]. Specifically, polynuclear cobalt complexes have attracted much attention in recent years due to their role as catalysts for light-driven water oxidation and in the photocatalytic trifluoromethylation of polycyclic aromatic hydrocarbons [35,36]. We have used the self-assembly process very successfully for generating spin-coupled coordination complexes of transition metal ions with macrocyclic [23,37-51] and non-cyclic [52-56] Schiff base ligands. In addition to polynucleating multidentate ligands, a majority of the coordination complexes also involve doubly or triply bridging anions like $\mathrm{N}_{3}^{-}, \mathrm{OH}^{-}, \mathrm{O}^{2-}, \mathrm{CH}_{3} \mathrm{O}^{-}, \mathrm{NCS}^{-}, \mathrm{N}(\mathrm{CN})_{2}^{-}, \mathrm{CN}^{-}$, and $\mathrm{C}_{2} \mathrm{H}_{3} \mathrm{O}_{2}{ }^{-} \mathrm{C}_{6} \mathrm{H}_{5} \mathrm{O}^{-}$ to generate extended network structures [57-62].

In continuation of our interest in the self-assembly, structural characterization, and magnetic properties of polynuclear transition metal and lanthanide coordination complexes exhibiting ferromagnetic and antiferromagnetic spin exchange interactions, we have explored the coordination versatility of the Schiff base ligands derived from the condensation of 2,6-diformyl-4-methylphenol (DFMP) with 2-aminoethanol, 1-amino-2-propanol, 2-amino-1,3-propanediol, and tris(hydroxymethyl)aminomethane with Copper(II) [52,54,55], Cobalt(II)/Cobalt(III) [53], and Nickel(II) [53,55,56]. These ligands have a high degree of conformational flexibility and the potential to coordinate in a convergent (directing the formation of the dinuclear units), and a divergent fashion (ability to extend coordination beyond the primary coordination mode), creating one-dimensional single chains, two-dimensional sheets, or three-dimensional network structures utilizing one, two, or three protonated/deprotonated hydroxymethyl/hydroxyethyl groups present in each side arm. 
In this publication, we want to report the synthesis, structural characterization, spectroscopic studies, and magnetic properties of dinuclear Cobalt(III), tetranuclear Cobalt(II), and mixed-valence Cobalt(II)/Cobalt(III) complexes with an incomplete double cubane core, which grow into beautiful 1D-single chains and 2D-sheet structures through $\mathrm{H}$-bonding-directed polymerization involving coordinated/uncoordinated hydroxy groups in the side arms of the ligands and methanol/water molecules $/ \mathrm{NO}_{3}{ }^{-}$ions in the crystal lattice.

\section{Materials and Methods}

\subsection{Physical Measurements}

Exactly same as reported in recently published paper [56].

\subsection{Materials}

2,6-Diformyl-4-methylphenol (DFMP) was isolated by the reported method [63], and 1-amino-2-propanol (AP) and tris(hydroxymethyl)aminomethane (THMAM) were supplied by Aldrich. All other chemicals (solvents and metal salts) used were analytical or reagent grade and were used without further purification. Schiff base ligands used in this investigation have not been isolated and structurally characterized. They have been generated in situ by reacting DFMP with AP $\left(\mathrm{H}_{3} \mathrm{~L}\right)$ and THMAM $\left(\mathrm{H}_{4} \mathrm{~L} 1\right)$ in the presence of the metal salts.

\subsection{X-ray Crystallography}

Suitable single crystals for X-ray diffraction studies were obtained for 1-4. Crystal data for the compounds were collected by the same method by mounting a crystal onto a thin glass fiber from a pool of Fluorolube ${ }^{\mathrm{TM}}$ and immediately placing it under a liquid $\mathrm{N}_{2}$ cooled stream, on a Bruker AXS diffractometer (Bruker AXS, Inc.: Madison, WI, USA) upgraded with an APEX II CCD detector (Bruker AXS, Inc.: Madison, WI, USA). The radiation used is graphite monochromatized Mo K $\alpha$ radiation $(\lambda=0.7107 \AA)$. The lattice parameters are optimized from a least-squares calculation on carefully centered reflections. Lattice determination, data collection, structure refinement, scaling, and data reduction were carried out using the APEX3 Version 2018.11 software (Bruker AXS, Inc.: Madison, WI, USA) package $[64,65]$. The data were corrected for absorption using the SCALE program within the APEX3 software (Version 6.45A, Bruker AXS, Inc.: Madison, WI, USA) package [64,65]. The structures were solved using SHELXT [66]. This procedure facilitated the assignment of C, N, Co, $\mathrm{O}$, and $\mathrm{Cl}$ atoms. Subsequent Fourier synthesis yielded the remaining atom positions. The hydrogen atoms are fixed in positions of ideal geometry (riding model) and refined within the XSHELL software (Version 6.12, Bruker AXS, Inc.: Madison, WI, USA) package [67]. The final refinement of each compound included anisotropic thermal parameters on all non-hydrogen atoms and was performed using OLEX2-1.2 [68]. The crystal data for compounds 1-4 are given in Table 1. Crystallographic data for the structures have been deposited with the Cambridge Crystallographic Data Centre as supplementary publication nos: CCDC-1948320-1948323. Copies of the data can be obtained free of charge on application to CCDC, 12 Union Road, Cambridge CB2 1EZ, UK (fax, +44-(0)1223-336033; or e-mail, deposit@ccdc.cam.ac.uk). Selected interatomic distances and angles for compounds 1-4 are listed in the Tables S1-S4. 
Table 1. Summary of crystallographic data for compounds $1-4$.

\begin{tabular}{|c|c|c|c|c|}
\hline Compound & 1 & 2 & 3 & 4 \\
\hline Empirical formula & $\mathrm{C}_{33} \mathrm{H}_{50} \mathrm{Cl}_{2} \mathrm{Co}_{2} \mathrm{~N}_{8} \mathrm{O}_{15}$ & $\mathrm{C}_{36} \mathrm{H}_{60} \mathrm{Cl}_{2} \mathrm{Co}_{4} \mathrm{~N}_{16} \mathrm{O}_{12}$ & $\mathrm{C}_{38} \mathrm{H}_{60} \mathrm{Co}_{4} \mathrm{~N}_{6} \mathrm{O}_{20}$ & $\mathrm{C}_{34} \mathrm{H}_{50} \mathrm{Co}_{4} \mathrm{~N}_{8} \mathrm{O}_{28}$ \\
\hline$M^{1}$ & 986.56 & 1215.62 & 1156.64 & 1254.54 \\
\hline Crystal System & triclinic & monoclinic & triclinic & monoclinic \\
\hline Space group & P-1 & $\mathrm{P} 2_{1} / \mathrm{c}$ & $\mathrm{P}-1$ & $\mathrm{P} 2{ }_{1} / \mathrm{c}$ \\
\hline $\mathrm{a} / \AA$ & $12.976(7)$ & $12.3537(13)$ & $9.594(3)$ & $10.9951(12)$ \\
\hline $\mathrm{b} / \AA ̊ \AA$ & $13.417(7)$ & $12.0935(13)$ & $11.947(4)$ & $18.435(2)$ \\
\hline$c / \AA$ & $13.652(7)$ & $18.306(2)$ & $12.238(4)$ & $14.5466(16)$ \\
\hline$\alpha /^{\circ}$ & $77.064(9)$ & - & $94.242(5)$ & - \\
\hline$\beta /{ }^{\circ}$ & $73.785(9)$ & $98.075(2)$ & $110.439(5)$ & $111.377(2)$ \\
\hline$\gamma /{ }^{\circ}$ & $85.693(9)$ & - & $104.116(4)$ & - \\
\hline$V / \AA^{3}$ & $2224(2)$ & $2707.8(5)$ & $1255.1(7)$ & $2745.7(5)$ \\
\hline$\rho_{\text {calcd }}\left(\mathrm{g} \mathrm{cm}^{-3}\right)$ & 1.473 & 1.491 & 1.530 & 1.517 \\
\hline$T / K$ & 180 & 105.15 & 105.15 & 190 \\
\hline Z & 2 & 2 & 1 & 2 \\
\hline$\mu / \mathrm{mm}^{-1}$ & 0.938 & 1.370 & 1.377 & 1.277 \\
\hline Crystal size (mm) & $0.20 \times 0.15 \times 0.10$ & $0.41 \times 0.25 \times 0.10$ & $0.2 \times 0.2 \times 0.1$ & $0.20 \times 0.2 \times 0.10$ \\
\hline \multicolumn{5}{|l|}{ Reflections collected: } \\
\hline Total & 17942 & 21211 & 9624 & 21677 \\
\hline Unique & 7850 & 4798 & 4410 & 4858 \\
\hline$R_{\text {int }}$ & 0.0973 & 0.0256 & 0.1010 & 0.0668 \\
\hline Final $R_{1}, w R_{2}$ & $0.0806,0.1931$ & $0.0334,0.0929$ & $0.0533,0.1388$ & $0.0539,0.1262$ \\
\hline
\end{tabular}

\section{Results}

\subsection{Synthesis of Complexes}

Caution: Azide and perchlorate complexes of metal ions involving organic ligands are potentially explosive. Only small quantities of the complexes should be prepared and should be handled with care.

In some cases, there is a difference between the most reasonable formula based on the elemental analysis (analytical formula) and that obtained from X-ray crystallography. This is because the analysis was carried out on air-dried samples due to their explosive nature. For consistency, the x-ray formulae will be used throughout this report.

\section{2. $\left[\mathrm{Co}_{2}{ }^{I I I}\left(\mathrm{H}_{2} \mathrm{~L}^{-1}\right)_{2}\left(A P^{-1}\right)\left(\mathrm{N}_{3}\right)\right]\left(\mathrm{ClO}_{4}\right)_{2}(\mathbf{1})$}

1-amino-2-propanol (AP) (2.0 mmol, $0.15 \mathrm{~g})$ was dissolved in methanol (20 $\mathrm{mL})$, and a solution of DFMP (1.0 mmol, $0.16 \mathrm{~g})$ dissolved in hot methanol $(20 \mathrm{~mL})$ was added to it. The resultant yellow solution was stirred under reflux for $30 \mathrm{~min}$. A solution of $\mathrm{Co}\left(\mathrm{ClO}_{4}\right)_{2} \cdot 6 \mathrm{H}_{2} \mathrm{O}(2.2 \mathrm{mmol}, 0.82 \mathrm{~g})$ dissolved in methanol $(20 \mathrm{~mL})$ was added to it while stirring under reflux dropwise over a period of $5 \mathrm{~min}$. The reddish brown solution formed was refluxed further for $30 \mathrm{~min}$, and a solution of sodium azide $(2.0 \mathrm{mmol}, 0.13 \mathrm{~g})$ dissolved in a mixture of methanol:water $(5: 1 \mathrm{~mL})$ was added dropwise. The dark red clear solution formed was stirred under reflux for $1 \mathrm{~h}$ and filtered while hot. A total of $5 \mathrm{~mL}$ of ethanol was added to the filtrate and was kept at room temperature for slow evaporation. After four weeks, reddish brown crystals suitable for X-ray analysis were obtained. The crystals were separated and washed with ethanol $(2 \times 2 \mathrm{~mL})$. Yield, $0.14 \mathrm{~g}, 27.8 \%$. IR spectrum: 3445, 3294, 3243, $3142 \mathrm{~cm}^{-1}\left(v\left(\mathrm{OH}\right.\right.$ or $\left.\left.\mathrm{NH}_{2}\right) \mathrm{H}_{2} \mathrm{O} / \mathrm{AP}^{-1}\right), 2027 \mathrm{~cm}^{-1}\left(v_{\text {as }}\left(\mathrm{N}_{3}\right)\right), 1651 \mathrm{~cm}^{-1}(v(\mathrm{C}=\mathrm{N})), 1095,1043,995 \mathrm{~cm}^{-1}$ $v\left(\mathrm{ClO}_{4}{ }^{-}\right)$. UV-Vis Spectrum: 430, 315, and $270 \mathrm{~nm}$ (Co-azide and Co-ligand charge transfer transitions, respectively), and $525 \mathrm{~nm}(\mathrm{~d}-\mathrm{d}$ transition). Elemental analysis (air-dried sample). Found (\%): $\mathrm{C}, 36.48$; $\mathrm{H}, 5.74 ; \mathrm{N}, 10.63$. Calcd. (\%) for $\left[\mathrm{Co}_{2}\left(\mathrm{C}_{15} \mathrm{H}_{21} \mathrm{~N}_{2} \mathrm{O}_{3}\right)_{2}\left(\mathrm{C}_{3} \mathrm{H}_{9} \mathrm{NO}\right)\left(\mathrm{N}_{3}\right)\right]\left(\mathrm{ClO}_{4}\right)_{2} \cdot 5 \mathrm{H}_{2} \mathrm{O}: \mathrm{C}, 36.75 ; \mathrm{H}, 5.70$; $\mathrm{N}, 10.39$. 


\section{3. $\left[\mathrm{Co}_{4}\left(\mathrm{H}_{2} \mathrm{~L}^{-1}\right)_{2}\left(\mu_{3}-1,1,1-\mathrm{N}_{3}\right)_{2}\left(\mu-1,1-\mathrm{N}_{3}\right)_{2} \mathrm{Cl}_{2}\left(\mathrm{CH}_{3} \mathrm{OH}\right)_{2}\right] \cdot 4 \mathrm{CH}_{3} \mathrm{OH}$ (2)}

Complex 2 was prepared by the same procedure as used for 1 except for replacing $\mathrm{Co}\left(\mathrm{ClO}_{4}\right)_{2} \cdot 6 \mathrm{H}_{2} \mathrm{O}$ with $\mathrm{CoCl}_{2} \cdot 6 \mathrm{H}_{2} \mathrm{O}(2.6 \mathrm{mmol}, 0.62 \mathrm{~g})$. After refluxing the reaction mixture for $2.5 \mathrm{~h}$, a blood red clear solution formed was filtered while hot and the filtrate was kept at ambient temperature for slow evaporation. After $24 \mathrm{~h}$, reddish brown crystals suitable for $\mathrm{X}$-ray studies were formed. The crystals were separated and washed with ethanol $(2 \times 2 \mathrm{~mL})$. Yield, $0.31 \mathrm{~g}, 53.7 \%$. IR spectrum: $3374 \mathrm{~cm}^{-1}$ $\left(v(\mathrm{OH}) \mathrm{H}_{2} \mathrm{O}\right.$ and/or $\left.\mathrm{CH}_{3} \mathrm{OH}\right), 2084 \mathrm{~cm}^{-1}\left(v_{\mathrm{as}}\left(\mathrm{N}_{3}\right)\right), 1648 \mathrm{~cm}^{-1}(v(\mathrm{C}=\mathrm{N}))$. UV-Vis Spectrum: 410, 390, and $310 \mathrm{~nm}$ (Co-azide and Co-ligand charge transfer transitions, respectively), and 680, 655, 605, $595 \mathrm{~nm}$ (d-d transition). Elemental analysis (air-dried sample). Found (\%): C, 31.16; H, 5.28; N, 18.77. Calcd. (\%) for $\left[\mathrm{Co}_{4}\left(\mathrm{C}_{15} \mathrm{H}_{21} \mathrm{~N}_{2} \mathrm{O}_{3}\right)_{2}\left(\mathrm{CH}_{3} \mathrm{OH}\right)_{2}\left(\mathrm{~N}_{3}\right)_{4} \mathrm{Cl}_{2}\right] \cdot 7 \mathrm{H}_{2} \mathrm{O}: \mathrm{C}, 31.50 ; \mathrm{H}, 5.29 ; \mathrm{N}, 18.38$.

\section{4. $\left[\mathrm{Co}_{2}{ }^{\mathrm{II}} \mathrm{Co}_{2}{ }^{\mathrm{III}}\left(\mathrm{HL}^{-2}\right)_{2}\left(\mu-\mathrm{CH}_{3} \mathrm{CO}_{2}\right)_{2}\left(\mu_{3-} \mathrm{OH}\right)_{2}\right]\left(\mathrm{NO}_{3}\right)_{2} \cdot 2 \mathrm{CH}_{3} \mathrm{CH}_{2} \mathrm{OH}$ (3)}

Complex 3 was obtained from a reaction carried out with the intention of getting a mixed metal $(\mathrm{Gd} / \mathrm{Co})$ complex but instead only a mixed-valence cobalt complex 3 was formed. To a methanolic solution $(5 \mathrm{~mL})$ of 1-amino-2-propanol $(0.50 \mathrm{mmol}, 0.040 \mathrm{~g})$, a solution of DFMP $(0.25 \mathrm{mmol}, 0.040 \mathrm{~g})$ dissolved in hot methanol $(10 \mathrm{~mL})$ was added. The resultant yellow solution of the Schiff base was stirred under reflux for $30 \mathrm{~min}$. To it, a solution of $\mathrm{Co}\left(\mathrm{NO}_{3}\right)_{2} \cdot 6 \mathrm{H}_{2} \mathrm{O}(0.70 \mathrm{mmol}, 0.200 \mathrm{~g})$ in methanol $(5 \mathrm{~mL})$ was added dropwise, while stirring under reflux. This was followed by the addition of a solution of $\mathrm{Gd}\left(\mathrm{CH}_{3} \mathrm{CO}_{2}\right)_{3} \cdot \mathrm{XH}_{2} \mathrm{O}(0.60 \mathrm{mmol}, 0.200 \mathrm{~g})$ in $5 \mathrm{~mL}$ of methanol. To the orange-red solution formed, a solution of triethylamine (TEA) $(0.80 \mathrm{mmol}, 0.080 \mathrm{~g})$ was added dropwise, and the reaction mixture was stirred under reflux for $40 \mathrm{~min}$. It was filtered while hot and the filtrate was left at room temperature for slow evaporation. After two weeks, the reddish brown residue left after the evaporation of the solvent was treated with $10 \mathrm{~mL}$ of ethanol. Most of the solid dissolved leaving behind some white solid which was discarded. After leaving the filtrate at room temperature for 10 weeks, reddish brown crystals suitable for X-ray analysis were formed. Some of the crystals were kept in the mother liquor for $\mathrm{X}$-ray analysis and the rest were filtered off and washed with ethanol $(2 \times 1 \mathrm{~mL})$. In this reaction, the presence of both $\mathrm{CH}_{3} \mathrm{CO}_{2}{ }^{-}$and $\mathrm{NO}_{3}{ }^{-}$ ions or $\mathrm{Gd}^{3+}$ ion seems to play an important role for the formation of complex 3 . When this reaction was carried out with only $\mathrm{Co}\left(\mathrm{CH}_{3} \mathrm{CO}_{2}\right)_{2}$ or $\mathrm{Co}\left(\mathrm{NO}_{3}\right)_{2}$, the desired compound was not obtained. Yield, $0.115 \mathrm{~g}, 78.8 \%$. IR spectrum: $3420 \mathrm{~cm}^{-1}\left(\mathrm{v}(\mathrm{OH}) \mathrm{H}_{2} \mathrm{O}\right.$ and/or $\left.\mathrm{CH}_{3} \mathrm{CH}_{2} \mathrm{OH}\right), 1647,1637 \mathrm{~cm}^{-1}$ $\left.v(\mathrm{C}=\mathrm{N}) / \mathrm{CH}_{3} \mathrm{CO}_{2}{ }^{-}\right)$. UV-Vis Spectrum: $400 \mathrm{~nm}$ and $310 \mathrm{~nm}$ (Co-ligand charge transfer transitions), and $550 \mathrm{~nm}$ (d-d transition). Elemental analysis (air-dried sample). Found (\%): C, 35.79; H, 5.04; N, 7.34. Calcd. (\%) for $\left[\mathrm{Co}_{2}{ }^{\mathrm{II}} \mathrm{Co}_{2}{ }^{\mathrm{III}}\left(\mathrm{C}_{15} \mathrm{H}_{20} \mathrm{~N}_{2} \mathrm{O}_{3}\right)_{2}\left(\mathrm{CH}_{3} \mathrm{CO}_{2}\right)_{2}(\mathrm{OH})_{2}\right]\left(\mathrm{NO}_{3}\right)_{2} \cdot \mathrm{CH}_{3} \mathrm{CH}_{2} \mathrm{OH} \cdot 5 \mathrm{H}_{2} \mathrm{O}: \mathrm{C}, 36.01$; $\mathrm{H}, 5.37 ; \mathrm{N}, 7.00$.

\section{5. $\left[\mathrm{Co}_{2}{ }^{\mathrm{II}} \mathrm{Co}_{2}{ }^{\mathrm{III}}\left(\mathrm{H}_{2} \mathrm{L1}^{-2}\right)_{2}\left(\mathrm{THMAM}^{-1}\right)_{2}\right]\left(\mathrm{NO}_{3}\right)_{4}$ (4)}

Tris(hydroxymethyl)aminomethane (THMAM) $(1.0 \mathrm{mmol}, 0.12 \mathrm{~g})$ was dissolved in $10 \mathrm{~mL}$ of methanol and a solution of DFMP $(0.50 \mathrm{mmol}, 0.080 \mathrm{~g})$ in $10 \mathrm{~mL}$ of hot methanol $(10 \mathrm{~mL})$ was added to it. The reaction mixture was stirred under reflux for $30 \mathrm{~min}$. A solution of $\mathrm{Co}\left(\mathrm{NO}_{3}\right)_{2} \cdot 6 \mathrm{H}_{2} \mathrm{O},(1.2 \mathrm{mmol}$, $0.365 \mathrm{~g}$ ) in $10 \mathrm{~mL}$ of methanol was added to it dropwise while stirring under reflux. The reddish brown solution formed was stirred under reflux for $15 \mathrm{~min}$, and 10 drops of triethylamine (TEA) were added to it. A dark red solution formed was stirred under reflux for about $2.0 \mathrm{~h}$ and filtered while hot. The filtrate was left at ambient temperature for slow evaporation. After two weeks, reddish brown crystals suitable for $\mathrm{X}$-ray analysis were formed. The crystals were filtered and washed with methanol $(2 \times 1 \mathrm{~mL})$. Yield: $0.095 \mathrm{~g}, 34.4 \%$. IR spectrum: $3333 \mathrm{~cm}^{-1}, 3179 \mathrm{~cm}^{-1}\left(v\left(\mathrm{OH} / \mathrm{NH}_{2}\right) \mathrm{H}_{2} \mathrm{~L}^{2-} / \mathrm{THMAM}\right)$, $1647 \mathrm{~cm}^{-1}, 1638 \mathrm{~cm}^{-1} v(\mathrm{C}=\mathrm{N} / \mathrm{C}=\mathrm{O})$. UV-Vis Spectrum: 440, 415, and $320 \mathrm{~nm}$ (Co-ligand charge transfer transitions), and 650, $525 \mathrm{~nm}$ (d-d transition). Elemental analysis (air-dried sample). Found (\%): $\mathrm{C}$, 35.78; $\mathrm{H}, 4.49 ; \mathrm{N}$, 9.73. Calcd. (\%) for $\left[\mathrm{Co}_{2}{ }^{\mathrm{II}} \mathrm{Co}_{2}{ }^{\mathrm{III}}\left(\mathrm{C}_{13} \mathrm{H}_{15} \mathrm{NO}_{5}\right)_{2}\left(\mathrm{C}_{4} \mathrm{H}_{10} \mathrm{NO}_{3}\right)_{2}\right]\left(\mathrm{NO}_{3}\right)_{4}: \mathrm{C}, 35.93 ; \mathrm{H}, 4.43$; $\mathrm{N}, 9.86$. 


\section{Discussion}

\subsection{Synthesis of the Complexes}

In this publication, we wish to report the self-assembly, structural characterization, and magnetic properties of cobalt(II) (2), cobalt(III) (1), and mixed-valence $\left(\mathrm{Co}_{2}{ }^{\mathrm{II}} / \mathrm{Co}_{2}{ }^{\mathrm{III}}\right)$ (3 and 4) complexes of two very versatile Schiff base: $\mathrm{H}_{3} \mathrm{~L}$ (a double Schiff base, potentially pentadentate $\left(\mathrm{N}_{2} \mathrm{O}_{3}\right)$ trianionic ligand) and $\mathrm{H}_{4} \mathrm{~L} 1$ (a single Schiff base, potentially hexadentate $\left(\mathrm{NO}_{5}\right)$, tetraanionic ligand) with a high degree of conformational flexibility (Figure 1). In complex 2, H-bonding directs the polymerization of ferromagnetically coupled tetranuclear cobalt(II) units with an incomplete double cubane core to 1D-single chains. In complex $4, \mathrm{H}$-bonding directs the formation of a polynuclear complex in which tetranuclear mixed-valence $\left(\mathrm{Co}_{2}{ }^{\mathrm{II}} \mathrm{Co}_{2}{ }^{\mathrm{III}}\right)$ units are interconnected by a network of $\mathrm{H}$-bonding along the $b c$-axis to produce a beautiful 2D-sheet structure.<smiles>CC=C(C)C=NC(CO)(CO)CO</smiles>

DFMP$$
\mathrm{H}_{7} \mathbf{L} \mathbf{3}
$$<smiles>C=CC(=C)C=NC(CO)(CO)CO</smiles><smiles>NC(CO)(CO)CO</smiles>
$+2$<smiles>Cc1cc(C=O)c(O)c(/C=N/CCO)c1</smiles><smiles>[141IH]</smiles><smiles>NC(CO)CO</smiles>

APD<smiles>CC=NC(CO)CO</smiles>

\section{$\mathrm{H}_{5} \mathrm{~L} 2$}

Figure 1. Structures of Schiff base ligands. DFMP $=2,6$-diformy1-4-methylphenol, THMAM = tris(hydroxymethyl)aminomethane, AP = 1-amino-2-propanol. 
We have carried out a series of reactions between DFMP and 1-amino-2-propanol (AP)/tri(hydroxymethyl)aminomethane (THMAM) in the presence of cobalt(II) salts, $\mathrm{CoX}_{2}\left(\mathrm{X}=\mathrm{CH}_{3} \mathrm{CO}_{2}{ }^{-}, \mathrm{NO}_{3}{ }^{-}, \mathrm{Cl}, \mathrm{ClO}_{4}^{-}\right) / \mathrm{NaN}_{3} / \mathrm{TEA}$ under varied reaction conditions to investigate the effects of various anions $\left(\mathrm{Cl}^{-}, \mathrm{NO}_{3}{ }^{-}, \mathrm{CH}_{3} \mathrm{CO}_{2}{ }^{-}, \mathrm{ClO}_{4}{ }^{-}\right)$on the formation of metal clusters with different nuclearities and also on the degree of deprotonation and coordination abilities of the Schiff base ligands (Scheme 1). Earlier [23,52-56,69], we have seen that the nature of the anions, nature of the metal ions, and the reaction conditions (presence/absence of TEA) have remarkable effects on the formation of the ligand, self-assembly of dinuclear, tetranuclear, pentanuclear, hexanuclear, heptanuclear, or decanuclear coordination compounds, in which H-bondings direct the formation of 1D-single chains, 2D-sheets, and 3D-network structures.
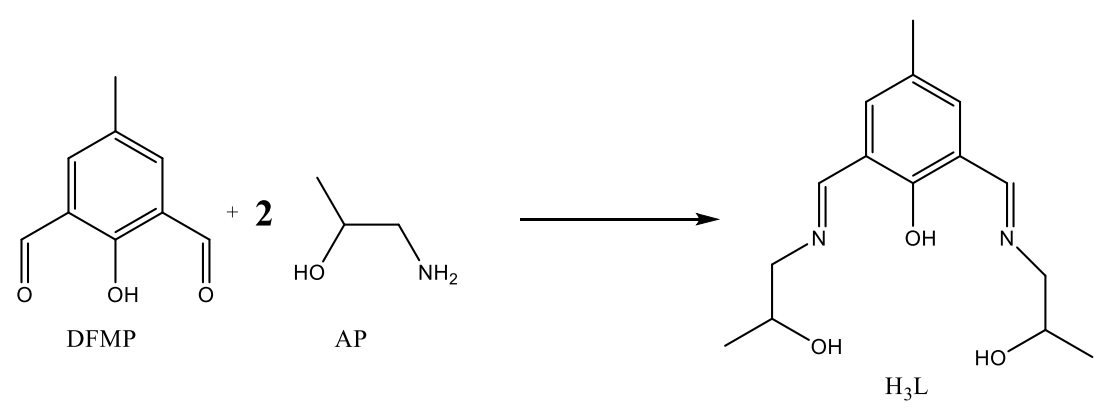

Scheme 1. Reactions between DFMP and AP in the presence of Co(II) salts form dinuclear $\mathrm{Co}(\mathrm{III})$ complex $\left[\mathrm{Co}_{2}{ }^{\mathrm{III}}\left(\mathrm{H}_{2} \mathrm{~L}^{-1}\right)_{2}\left(\mathrm{AP}^{-1}\right)\left(\mathrm{N}_{3}\right)\right]\left(\mathrm{ClO}_{4}\right)_{2}$ (1), tetranuclear $\mathrm{Co}$ (II) complex $\left[\mathrm{Co}_{4}\left(\mathrm{H}_{2} \mathrm{~L}^{-1}\right)_{2}\left(\mu_{3}-1,1,1-\mathrm{N}_{3}\right)_{2}\left(\mu-1,1-\mathrm{N}_{3}\right)_{2} \mathrm{Cl}_{2}\left(\mathrm{CH}_{3} \mathrm{OH}\right)_{2}\right] \cdot 4 \mathrm{CH}_{3} \mathrm{OH}(2)$, and tetranuclear mixed-valence complex $\left[\mathrm{Co}_{2}{ }^{\mathrm{II}} \mathrm{Co}_{2}{ }^{\mathrm{III}}\left(\mathrm{HL}^{-2}\right)_{2}\left(\mu-\mathrm{CH}_{3} \mathrm{CO}_{2}\right)_{2}\left(\mu_{3} \mathrm{OH}\right)_{2}\right]\left(\mathrm{NO}_{3}\right)_{4} \cdot 2 \mathrm{CH}_{3} \mathrm{CH}_{2} \mathrm{OH}$ (3) of a double Schiff base ligand $\mathrm{H}_{3} \mathrm{~L}$.

In complex 4, DFMP and tris(hydroxymethyl)aminomethane (THMAM) were reacted in the presence of $\mathrm{Co}\left(\mathrm{NO}_{3}\right)_{2} \cdot 6 \mathrm{H}_{2} \mathrm{O}$ and $\mathrm{Gd}\left(\mathrm{CH}_{3} \mathrm{CO}_{2}\right)_{3} \cdot \times \mathrm{H}_{2} \mathrm{O}$ in a 1:2:2.5:2 mole ratio with an intention to get a dinuclear or tetranuclear $\mathrm{Co}(\mathrm{II}) / \mathrm{Gd}(\mathrm{III})$ mixed metal complex of double Schiff base ligand $\mathrm{H}_{7} \mathrm{~L} 3$ but instead we got a mixed-valence tetranuclear complex $\left[\mathrm{Co}_{2}{ }^{\mathrm{II}} \mathrm{Co}_{2}{ }^{\mathrm{III}}\left(\mathrm{H}_{2} \mathrm{~L}^{-2}\right)_{2}\left(\mathrm{THMAM}^{-1}\right)_{2}\right]\left(\mathrm{NO}_{3}\right)_{4}(4)$ of a single Schiff base ligand $\mathrm{H}_{4} \mathrm{~L} 1$ (Scheme 2) formed from $1+1$ condensation of DFMP and THMAM. The formation of a single Schiff base ligand $\left(\mathrm{H}_{4} \mathrm{~L} 1\right)$ present in 4 contrary to a double Schiff base ligand $\left(\mathrm{H}_{7} \mathrm{~L} 3\right)$ formed in a pentanuclear copper(II) cluster $\left\{\left[\mathrm{Cu}_{2}\left(\mathrm{H}_{5} \mathrm{~L}^{2-}\right)\left(\mu-\mathrm{N}_{3}\right)\right]_{2}\left[\mathrm{Cu}\left(\mathrm{N}_{3}\right)_{4}\right] \cdot 2 \mathrm{CH}_{3} \mathrm{OH}\right\}_{n}$, (to the best of our knowledge, the only complex reported with this ligand) [52,55], is presumably due to either cobalt(II) assisted partial hydrolysis of one of the two arms of an initially formed double Schiff base ligand $\left(\mathrm{H}_{7} \mathrm{~L}\right)$ as we reported earlier [55] in hexanuclear nickel(II) complexes or due to the preferential stereochemical requirements of mixed-valence tetranuclear $\left[\mathrm{Co}_{2}{ }^{\mathrm{II}} \mathrm{Co}_{2}{ }^{\mathrm{III}}\right]$ complex $4[53,70,71]$. Recently, we [53,55,56] and Ray's group [72] have reported the partial hydrolysis of one of the side arms of $\mathrm{H}_{7} \mathrm{~L} 3 / \mathrm{H}_{5} \mathrm{~L} 2$ (Figure 1) or similar double Schiff base ligand (formed by $1+2$ condensation of DFMP and 2-aminoethanol) in hexanickel $\left(\mathrm{Ni}^{\mathrm{II}}{ }_{6}\right)$ clusters. Based on present and earlier investigations $[52,53,55,56,69]$ with Schiff base ligands derived from DFMP, we can conclude that the formation of a single Schiff base ligand $\left(\mathrm{H}_{4} \mathrm{~L} 1\right)$ instead of a double Schiff base ligand $\left(\mathrm{H}_{7} \mathrm{~L} 3\right)$ is the result of either metal-catalyzed partial hydrolysis or preferential $1+1$ condensation in case of hexanuclear Nickel(II) or mixed-valence tetranuclear cobalt complexes due to stereochemical requirements of these metals. 

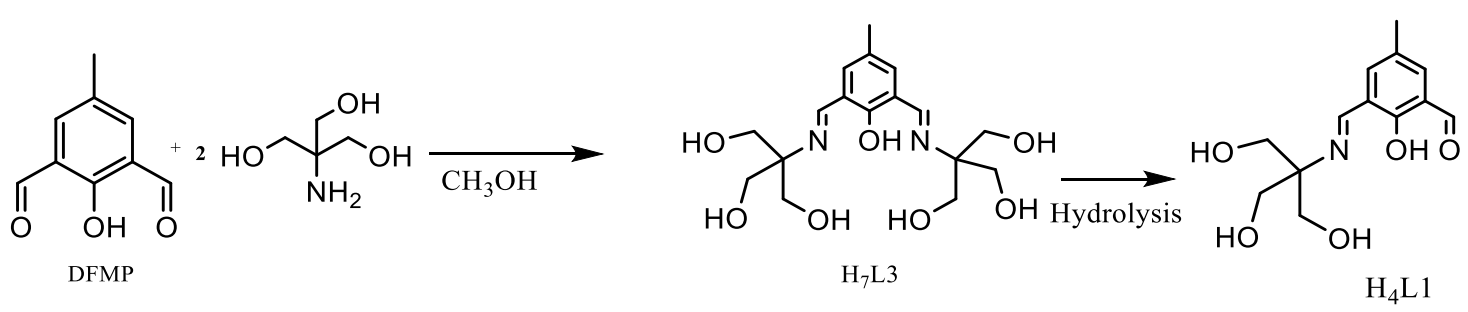

Scheme 2. Reactions between DFMP and THMAM in the presence of $\mathrm{Co}\left(\mathrm{NO}_{3}\right)_{2} \cdot 6 \mathrm{H}_{2} \mathrm{O} / \mathrm{TEA}$ produces a mixed-valence tetranuclear complex $\left[\mathrm{Co}_{2}{ }^{\mathrm{II}} \mathrm{Co}_{2}{ }^{\mathrm{III}}\left(\mathrm{HL}^{-2}\right)_{2}\left(\mathrm{THMAM}^{-}\right)_{2}\right]\left[\mathrm{NO}_{3}\right]_{4}(4)$ of $\mathrm{H}_{4} \mathrm{~L} 1$.

\subsection{Description of Structures}

\subsection{1. $\left[\mathrm{Co}_{2}{ }^{\mathrm{III}}\left(\mathrm{H}_{2} \mathrm{~L}^{-1}\right)_{2}\left(\mathrm{AP}^{-1}\right)\left(\mathrm{N}_{3}\right)\right]\left(\mathrm{ClO}_{4}\right)_{2}(\mathbf{1})$}

Reaction between DFMP and 1-amino-2-propanol (AP) in the presence of $\mathrm{Co}\left(\mathrm{ClO}_{4}\right)_{2} \cdot 6 \mathrm{H}_{2} \mathrm{O} / \mathrm{NaN}_{3} / \mathrm{TEA}$ in methanol (in air) results in the formation of a dinuclear $\mathrm{Co}$ (III) complex $\left[\mathrm{Co}_{2}{ }^{\mathrm{III}}\left(\mathrm{H}_{2} \mathrm{~L}^{-1}\right)_{2}\left(\mathrm{AP}^{-1}\right)\left(\mathrm{N}_{3}\right)\right]\left(\mathrm{ClO}_{4}\right)_{2}(\mathbf{1})$. The cationic core in the structure of $\mathbf{1}$ is shown in Figure 2. Bond angles and distances relevant to the cobalt(III) coordination core are given in Table S1. Complex $\mathbf{1}$ crystallizes in triclinic system space group P-1 and is comprised of two $\mathrm{Co}^{3+}$ ions, two $\mathrm{H}_{2} \mathrm{~L}^{-1}$ ligands, one deprotonated $\mathrm{AP}^{-1}$, and one terminal azide ion. $\mathrm{H}_{3} \mathrm{~L}$, potentially a pentadentate trianionic ligand, in $\mathbf{1}$ behaves as a tridentate $\left(\mathrm{NO}_{2}\right)$ monoanionic $\left(\mathrm{H}_{2} \mathrm{~L}^{-1}\right)$ ligand which is contrary to its behavior as a pentadenate/tetradentate di-anionic ligand in $\mathrm{Cu}$ (II) [69], Ni(II) [56], and other cobalt(II) complex (2), and mixed-valence $\mathrm{Co}_{2}{ }^{\mathrm{II}} / \mathrm{Co}_{2}{ }^{\mathrm{III}}$ complex (3). The stereochemistry at $\mathrm{Co}(1)$ in an asymmetric dinuclear unit can best be described as a distorted octahedral with phenoxide $\mathrm{O}$, alkoxide $\mathrm{O}$, an azido nitrogen $\mathrm{N}$, and an alkoxide $\mathrm{O}$ of $\mathrm{AP}^{-1}$ atoms in the equatorial plane and an imine nitrogen of the ligand and an alkoxide $\mathrm{O}$ of $\mathrm{AP}^{-1}$ in the axial plane. The geometry at $\mathrm{Co}(2)$ is defined by phenoxide $\mathrm{O}$, two alkoxide $\mathrm{O}$ atoms of the ligands, and an imine $\mathrm{N}$ of $\mathrm{AP}^{-1}$ atoms in the equatorial plane and an alkoxide $\mathrm{O}$ of $\mathrm{AP}^{-1}$ and an imine $\mathrm{N}$ of the ligand $\mathrm{H}_{2} \mathrm{~L}^{-1}$ in the axial plane. The unique feature of this complex is that all distances equatorial and axial are less than $2.00 \AA$. The other unique feature of this complex is that the metal-metal distance is 2.5430 (11) $\AA$, which is short enough to make Co(III) as seven coordinate, a rare coordination number for cobalt(III). Two Co(III) ions in the dinuclear unit are bridged by three single-atom bridges- $t$ two from alkoxide $\mathrm{O}$ atoms in the side arms of the ligands $\left(\mathrm{H}_{2} \mathrm{~L}^{-1}\right)$ and one from alkoxide $\mathrm{O}$ in $\mathrm{AP}^{-1}$, holding two metal centers in close proximity. The sum of the angles in the basal plane of $\mathrm{Co}(1)$ and $\mathrm{Co}(2)$ are $359.5(2)^{\circ}$ and $358.6(2)^{\circ}$, respectively, indicating planar arrangements around these metal centers. The $\mathrm{Co}-\mathrm{N}$ and $\mathrm{Co}-\mathrm{O}$ bond distances in the basal plane lie in the ranges 1.848 (6)-1.869 (6) $\AA$ and 1.874 (5)-1.943 (5) $\AA$, respectively, which are significantly shorter than the distances in $\mathrm{Co}(\mathrm{II})$ complex 2 of this ligand. The $\mathrm{Co}-\mathrm{N}$ and $\mathrm{Co}-\mathrm{O}$ bond distances in the axial plane are quite short and lie in the ranges 1.934 (6)-1.939 (7) $\AA$ and 1.943 (5)-1.968 (5) $\AA$, respectively. The sum of the angles around the alkoxide bridging $\mathrm{O}$-atoms, $\mathrm{O}(3), \mathrm{O}(4)$, and $\mathrm{O}(5)$ are $312.7(4)^{\circ}, 312.8(4)^{\circ}$, and $310.6(6)^{\circ}$, respectively, indicating pyramidal distortion at these atoms. 


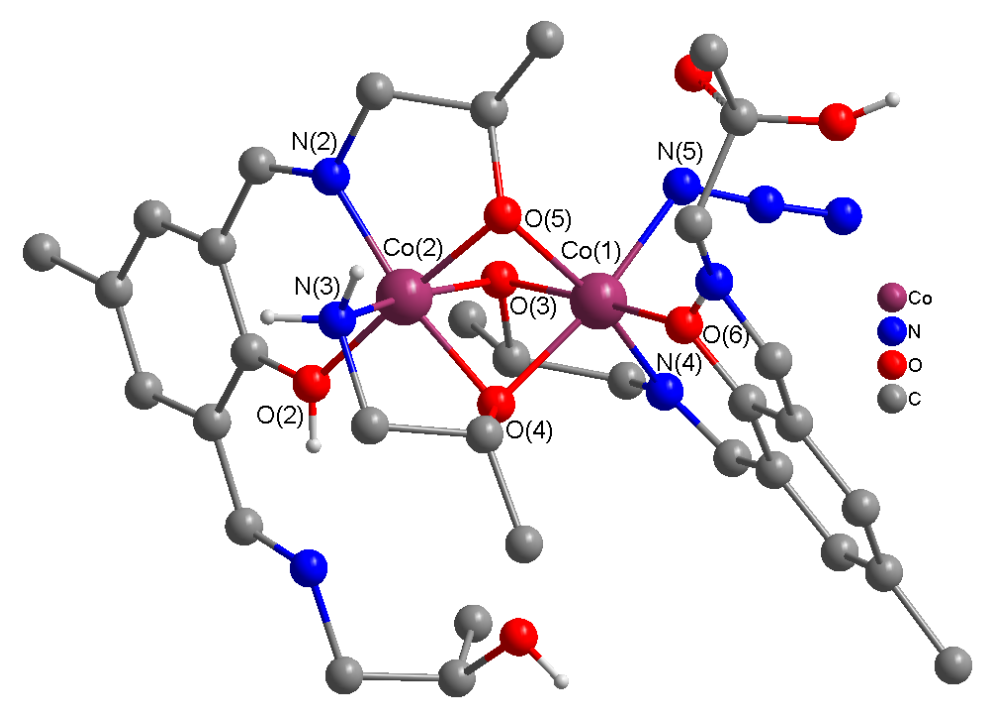

Figure 2. Molecular structure of a dinuclear unit $\left[\mathrm{Co}_{2}{ }^{\mathrm{III}}\left(\mathrm{H}_{2} \mathrm{~L}^{-1}\right)_{2}\left(\mathrm{AP}^{-1}\right)\left(\mathrm{N}_{3}\right)\right]\left(\mathrm{ClO}_{4}\right)_{2}(\mathbf{1})$ with numbering of atoms in the coordination environment. $\mathrm{H}$ atoms are omitted for clarity. Note: In $\mathbf{1}$, there is one hydrogen missing because the oxygen atom of the $\mathrm{OH}$ group is disordered over two positions. The disordered oxygen atom has been modeled with partial occupancies and is located where the hydrogen atom would be located. We cannot assign a hydrogen atom to that carbon atom due to this issue. Thus, the sum formula is short a hydrogen atom.

\subsection{2. $\left[\mathrm{Co}_{4}\left(\mathrm{H}_{2} \mathrm{~L}^{-1}\right)_{2}\left(\mu_{3}-1,1,1-\mathrm{N}_{3}\right)_{2}\left(\mu-1,1-\mathrm{N}_{3}\right)_{2} \mathrm{Cl}_{2}\left(\mathrm{CH}_{3} \mathrm{OH}\right)_{2}\right] \cdot 4 \mathrm{CH}_{3} \mathrm{OH}$ (2)}

Complex 2 is obtained by reacting DFMP with 1-amino-2-propanol in the presence of $\mathrm{CoCl}_{2} \cdot 6 \mathrm{H}_{2} \mathrm{O} / \mathrm{TEA} / \mathrm{NaN}_{3}$, crystallizing in the monoclinic system with space group $\mathrm{P} 2_{1} / \mathrm{c}$. Complex 2 has a centrosymmetric tetranuclear Cobalt(II) core $\left[\mathrm{Co}_{4}\left(\mathrm{H}_{2} \mathrm{~L}^{-1}\right)_{2}\left(\mu_{3}-1,1,1-\mathrm{N}_{3}\right)_{2}\left(\mu-1,1-\mathrm{N}_{3}\right)_{2} \mathrm{Cl}_{2}\left(\mathrm{CH}_{3} \mathrm{OH}\right)_{2}\right] \cdot 4 \mathrm{CH}_{3} \mathrm{OH}$ (2) in which two imperfect cubanes are fused. The structure of neutral tetranuclear core of $\mathbf{2}$ is shown in Figure 3 and the relevant bond angles and bond distances for $\mathbf{2}$ are given in Table S2. In each tetranuclear core, two dinuclear units $\left(\left[\mathrm{Co}_{2}\left(\mathrm{H}_{2} \mathrm{~L}^{-1}\right)\left(\mu_{3}-1,1,1-\mathrm{N}_{3}\right)\left(\mu-1,1-\mathrm{N}_{3}\right) \mathrm{Cl}\left(\mathrm{CH}_{3} \mathrm{OH}\right)\right]\right)$ are interconnected through two triply bridging end-on (EO) $\mu_{3}-\mathrm{N}_{3}$ ions and two doubly bridging $\mathrm{EO}\left(\mu-\mathrm{N}_{3}\right)$ azide ions. Each dinuclear unit involves one monoanionic tetradenate double Schiff base ligand $\left(\mathrm{H}_{2} \mathrm{~L}^{-1}\right)$, one methanol molecule, one chloride ion, one $\mathrm{EO} \mu-\mathrm{N}_{3}$ ions which provides interdimer bridge, and one $\mathrm{EO} \mu_{3}-\mathrm{N}_{3}$ ion which provides intradimer and interdimer bridges. We believe the self-assembly of tetranuclear complex 2 is the result of stereochemical requirements of the cobalt centers.

In $2, \mathrm{H}_{3} \mathrm{~L}$ behaves as a tetradentate $\left(\mathrm{N}_{2} \mathrm{O}_{2}\right)$ monoanionic $\left(\mathrm{H}_{2} \mathrm{~L}^{--}\right)$ligand, and one hydroxy group in one side arm of the double Schiff base ligand $\left(\mathrm{H}_{3} \mathrm{~L}\right)$ remains protonated and uncoordinated. The intradimer and interdimer Co-Co distances of 3.1598 (2) $\AA$ and 3.2927 (3) $\AA$, respectively, are much longer compared to $\mathbf{1}$ (2.543 (11) $\AA$ ). This is consistent with Co(III) ions in $\mathbf{1}$ and Co(II) ions in 2. In each dinuclear unit, two Cobalt(II) ions are bridged by phenoxide oxygen $(\mathrm{O}(1))$ and an azido nitrogen $(\mathrm{N}(3))$ for effective spin-exchange interactions. The sum of the bond angles at $\mu$-phenoxide oxygen $(\mathrm{O}(1))$, azide nitrogens $\left[\mu-\mathrm{N}_{3}(\mathrm{~N}(6))\right.$ and $\mu_{3}-\mathrm{N}_{3}(\mathrm{~N}(3)]$ are $357.11(13)^{\circ}, 357.31(15)^{\circ}$, and $290.8(9)^{\circ}$, respectively, and are indicative of slight distortion from planarity at $\mathrm{O}(1)$ and $\mathrm{N}(6)$ and cubic distortion at $\mathrm{N}(3)$ atoms. These bridges can provide effective superexchange interactions between the $\mathrm{Co}(\mathrm{II})$ ions in the tetranuclear core. All azides are almost linear $\left(\mathrm{N}-\mathrm{N}-\mathrm{N}=178.5(3)-178.6(3)^{\circ}\right)$. The intradimer bridge angles at the phenoxide oxygen $(\mathrm{O}(1))$ and azide nitrogen $(\mathrm{N}(3))$ are $100.36(8)^{\circ}$ and $93.85(9)^{\circ}$, respectively, and provide pathways for antiferromagnetic and ferromagnetic interactions, respectively. The interdimer bridge angles at $\mathrm{N}(6)\left(\mu-\mathrm{N}_{3}\right)$ and $\mathrm{N}(3)\left(\mu_{3}-\mathrm{N}_{3}\right)$ are $103.36(9)^{\circ}$ and $97.29(8)-99.68(9)^{\circ}$, respectively, are indicative of ferromagnetic spin exchange interactions between cobalt centers (vide supra). The stereochemistry at each Cobalt(II) ion is distorted octahedral. The Co-O 


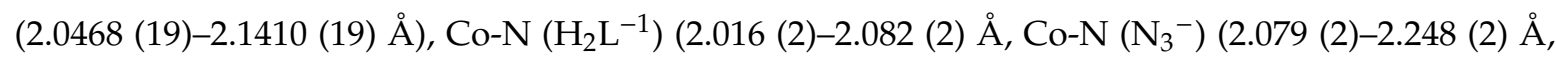
and $\mathrm{Co}-\mathrm{Cl}(2.4751980 \AA)$ distances are normal and fall in the range reported for octahedral Nickel(II) [56] and Cobalt(II) complexes with this and similar Schiff base ligands.

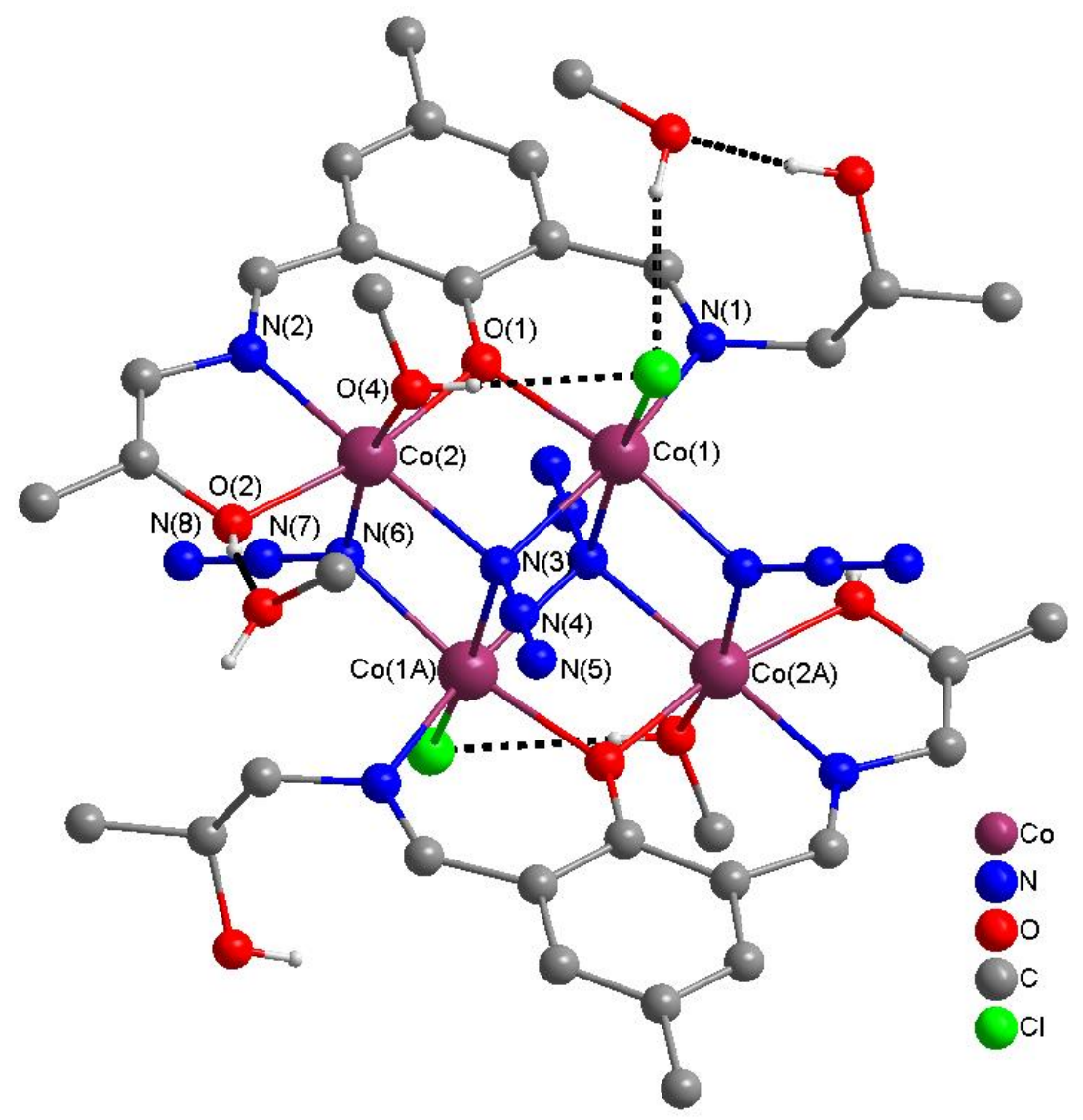

Figure 3. Molecular structure of a neutral centrosymmetric tetranuclear unit $\left[\mathrm{Co}_{4}\left(\mathrm{H}_{2} \mathrm{~L}^{-1}\right)_{2}\left(\mu_{3}-1,1,1-\mathrm{N}_{3}\right)_{2}\left(\mu-1,1-\mathrm{N}_{3}\right)_{2} \mathrm{Cl}_{2}\left(\mathrm{CH}_{3} \mathrm{OH}\right)_{2}\right] \cdot 4 \mathrm{CH}_{3} \mathrm{OH}$ (2) with numbering of atoms in the coordination environment. $\mathrm{H}$ atoms and solvent molecules are omitted for clarity. Atoms with $\mathrm{A}$ in their labels are symmetry generated.

H-bonding, which plays a dominating role in the stabilization of proteins and other biomolecules structures, direct the polymerization of the tetranuclear $\left[\mathrm{Co}_{4}\right]$ units producing $1 \mathrm{D}$-single chains (Figure 4), which are not connected in any way to form 2D-sheets or 3D-structures as observed in mixed-valence $\left[\mathrm{CO}_{2}{ }^{\mathrm{II}} \mathrm{Co}_{2}{ }^{\mathrm{III}}\right]$ tetranuclear complex 4. There are intramolecular H-bonding interactions between the coordinated chloride ion $(\mathrm{Cl}(1))$ and hydroxy group $(\mathrm{O}(4))$ of the coordinated methanol on one side $(3.038 \AA$ ) and hydroxy group $(\mathrm{O}(5))$ of the uncoordinated methanol (3.114 $\AA$ ) on the other side, which is further H-bonded ( $2.706 \AA)$ to the uncoordinated hydroxy group $(\mathrm{O}(3))$ in the side arm of the ligand $\left(\mathrm{H}_{2} \mathrm{~L}^{-}\right)$. The tetranuclear units are interconnected by remarkably strong symmetrical network of hydrogen bonding interactions (2.608-2.664 $\AA$ ) between hydroxy group $(\mathrm{O}(6))$ of the uncoordinated methanol molecule to the coordinated protonated hydroxy group $(\mathrm{O}(2))$ in the side arm of the ligand $\left(\mathrm{H}_{2} \mathrm{~L}^{-}\right)$and uncoordinated protonated hydroxy group $(\mathrm{O}(3))$ in the side arm of $\mathrm{H}_{2} \mathrm{~L}^{-}$in the neighboring molecule producing 1D-single chains (Figure 4). 


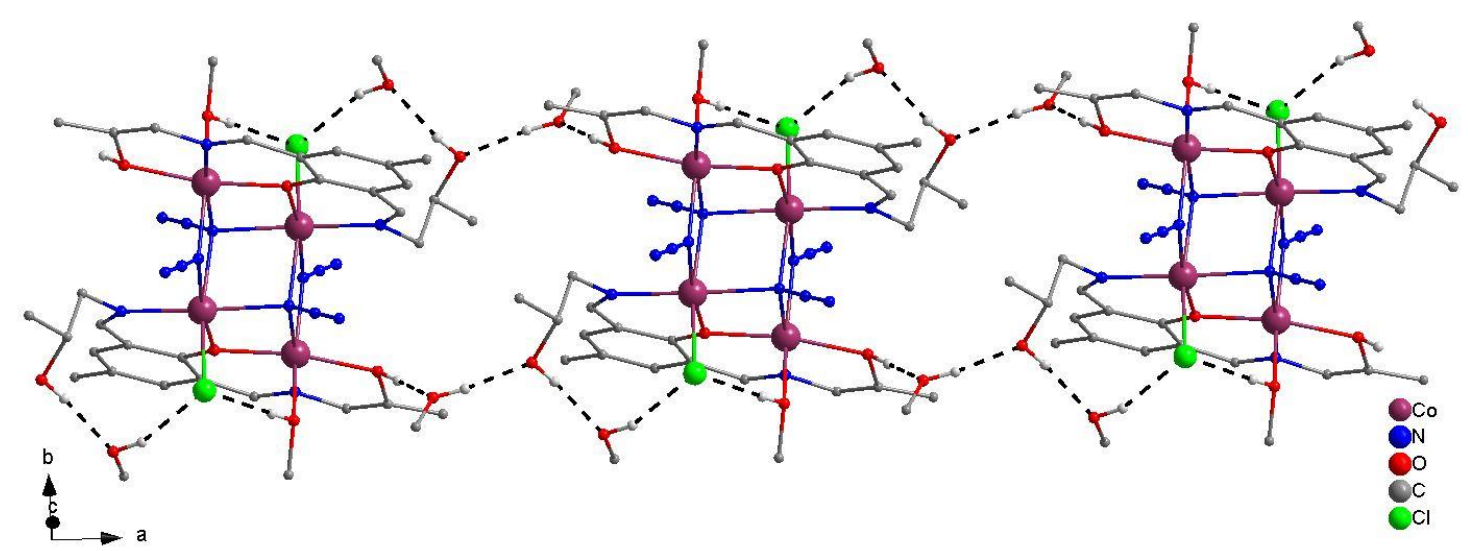

Figure 4. Perspective view of a H-bonding-directed 1D-single chains structure of 2 along the $a$-axis.

4.2.2.1. $\left[\mathrm{Co}_{2}{ }^{\mathrm{II}} \mathrm{Co}_{2}{ }^{\mathrm{III}}\left(\mathrm{HL}^{-2}\right)_{2}\left(\mu-\mathrm{CH}_{3} \mathrm{CO}_{2}\right)_{2}\left(\mu_{3}-\mathrm{OH}\right)_{2}\right]\left(\mathrm{NO}_{3}\right)_{2} \cdot 2 \mathrm{CH}_{3} \mathrm{CH}_{2} \mathrm{OH}$ (3)

The aerobic reaction between DFMP and 1-amino-2-propanol in the presence of $\mathrm{Co}\left(\mathrm{NO}_{3}\right)_{2} \cdot 6 \mathrm{H}_{2} \mathrm{O} / \mathrm{Gd}\left(\mathrm{CH}_{3} \mathrm{CO}_{2}\right)_{3} \cdot \mathrm{XH}_{2} \mathrm{O} / \mathrm{TEA}$ results in the formation of a mixed-valence tetranuclear complex $\left[\mathrm{Co}_{2}{ }^{\mathrm{II}} \mathrm{Co}_{2}{ }^{\mathrm{III}}\left(\mathrm{HL}^{-2}\right)_{2}\left(\mu-\mathrm{CH}_{3} \mathrm{CO}_{2}\right)_{2}\left(\mu_{3} \mathrm{OH}\right)_{2}\right]\left(\mathrm{NO}_{3}\right)_{2} \cdot 2 \mathrm{CH}_{3} \mathrm{CH}_{2} \mathrm{OH}$ (3). It is presumed that the presence of both $\mathrm{CH}_{3} \mathrm{CO}_{2}{ }^{-}$and $\mathrm{NO}_{3}{ }^{-}$ions or $\mathrm{Gd}$ (III) ion promotes the separation of 3. In 3, $\mathrm{H}_{3} \mathrm{~L}$ acts as a pentadentate $\left(\mathrm{N}_{2} \mathrm{O}_{3}\right)$, dianionic ligand $\left(\mathrm{HL}^{-2}\right)$ holding two metal centers in close proximity, whereas in $\mathbf{1}$ and $\mathbf{2}$ it behaves as a tridentate monoanionic or tetradentate monoanionic ligand, respectively. A perspective view of 3, along with relevant atomic labeling, is shown in Figure 5. The selected bond distances and angles relevant to cobalt coordination are given in Table S3. Complex 3 has a cationic centrosymmetric tetranuclear core $\left[\mathrm{Co}_{2}{ }^{\mathrm{II}} \mathrm{Co}_{2}{ }^{\mathrm{III}}\left(\mathrm{HL}^{-2}\right)_{2}\left(\mu-\mathrm{CH}_{3} \mathrm{CO}_{2}\right)_{2}\left(\mu_{3-} \mathrm{OH}\right)_{2}\right]^{+2}$ in which two imperfect cubanes are fused and each cobalt $\left(\mathrm{Co}^{\mathrm{II}} / \mathrm{Co}^{\mathrm{III}}\right)$ has distorted octahedral stereochemistry. In each dinuclear unit, $\mathrm{Co}$ (II) and $\mathrm{Co}$ (III) ions are bridged by two single atom bridges (a phenoxide oxygen $\mathrm{O}(1)(\mu-\mathrm{PhO})$ and a hydroxide oxygen $\mathrm{O}(3)\left(\mu_{3}-\mathrm{OH}\right)$ and an acetate ions $\left(1,3-\mathrm{CH}_{3} \mathrm{CO}_{2}{ }^{-}\right)$with a metal-metal separation of 2.9251 (10) $\AA$. Two dinuclear units are interconnected by two triply bridging $\left(\mu_{3}-\mathrm{OH}\right)$ hydroxide ions $(\mathrm{O}(3)$ and $\mathrm{O}(3 \mathrm{~A}))$ and two alkoxide ions $(\mathrm{O}(2)$ and $\mathrm{O}(2 \mathrm{~A})$ in the side arm of the ligand to form mixed-valence tetranuclear cationic core $\left[\mathrm{Co}_{2}{ }^{\mathrm{II}} \mathrm{Co}_{2}{ }^{\mathrm{III}}\left(\mathrm{HL}^{-2}\right)_{2}\left(\mu-\mathrm{CH}_{3} \mathrm{CO}_{2}\right)_{2}\left(\mu_{3-} \mathrm{OH}\right)_{2}\right]^{+2}$ with intermetallic separation of $3.0702(9) \AA(\mathrm{Co}(1)-\mathrm{Co}(2 \mathrm{~A}))$.

The coordination environment around $\mathrm{Co}^{\mathrm{III}}(1)$ and $\mathrm{Co}^{\mathrm{II}}(2)$ in the equatorial plane is defined by phenoxy oxygen $(\mathrm{O}(1))$, imino nitrogen $(\mathrm{N}(1) / \mathrm{N}(2))$, alkoxide oxygen $(\mathrm{O}(2) / \mathrm{O}(4))$, and hydroxide oxygen $(\mathrm{O}(3))$ and in the axial plane by acetate oxygen $(\mathrm{O}(5) / \mathrm{O}(6))$ and hydroxide oxygen $(\mathrm{O}(3 \mathrm{~A})) /$ alkoxide oxygen $(\mathrm{O}(2 \mathrm{~A}))$, respectively, in a distorted octahedral arrangement. The $\mathrm{Co}-\mathrm{N}$ and $\mathrm{Co}-\mathrm{O}$ distances ranging from 1.873 (4) to 2.036 (4) $\AA$ and 1.891 (3) to 2.131 (3) $\AA$ (Table S3) are very similar to the distances reported for similar mixed-valence cobalt complexes with simiar Schiff base ligands [53,70,71]. The Co-Co distances in the doubly bridged dinuclear and tetranuclear units are in the range 2.9288(16)-3.0702(9) $\AA$ which are slightly shorter than the distances reported in similar mixed-valence cobalt complexes [71]. There are two uncoordinated $\mathrm{NO}_{3}{ }^{-}$ions per tetranuclear unit in the lattice. In each dinuclear unit, the phenoxide bridge angle $\left(\mathrm{Co}(1)-\mathrm{O}(1)-\mathrm{Co}(2)\right.$ is $98.35(15)^{\circ}$ and the hydroxide $\left(\mu_{3}-\mathrm{OH}\right)$ bridge angle $(\mathrm{Co}(1)-\mathrm{O}(3)-\mathrm{Co}(2))$ is $94.63(15)^{\circ}$ which are significantly smaller than in complex 4 . The bridge angles at the doubly bridging ethanolate oxygen $(\mu-\mathrm{O})(\mathrm{Co}(1)-\mathrm{O}(2)-\mathrm{Co}(2 \mathrm{~A}))$ is $100.86(13)$ and the triply bridging hydroxide oxygen $\left(\mu_{3}-\mathrm{O}(3)\right)(\mathrm{Co}(1)-\mathrm{O}(3)-\mathrm{Co}(1 \mathrm{~A}))$ and $\mathrm{Co}(2)-\mathrm{O}(3)-\mathrm{Co}(1 \mathrm{~A})$, which bridge the two dimeric units in the tetranuclear core are $100.12(16)^{\circ}$ and $101.12(14)^{\circ}$, respectively. The solid angles at the phenoxide $\left(\mathrm{O}(1)\right.$, ethanolate $\left(\mu-\mathrm{O}(2)\right.$ and hydroxide oxygen $\left(\mu_{3}-\mathrm{O}(3)\right)$ atoms are $359.75(6)^{\circ}, 333.66(6)^{\circ}$, and $295.87(15)^{\circ}$, respectively, and are indicative of the $\mu$-planar, $\mu$-pyramidal, and $\mu_{3}$-cubic arrangements at these bridging centers [70,71]. 


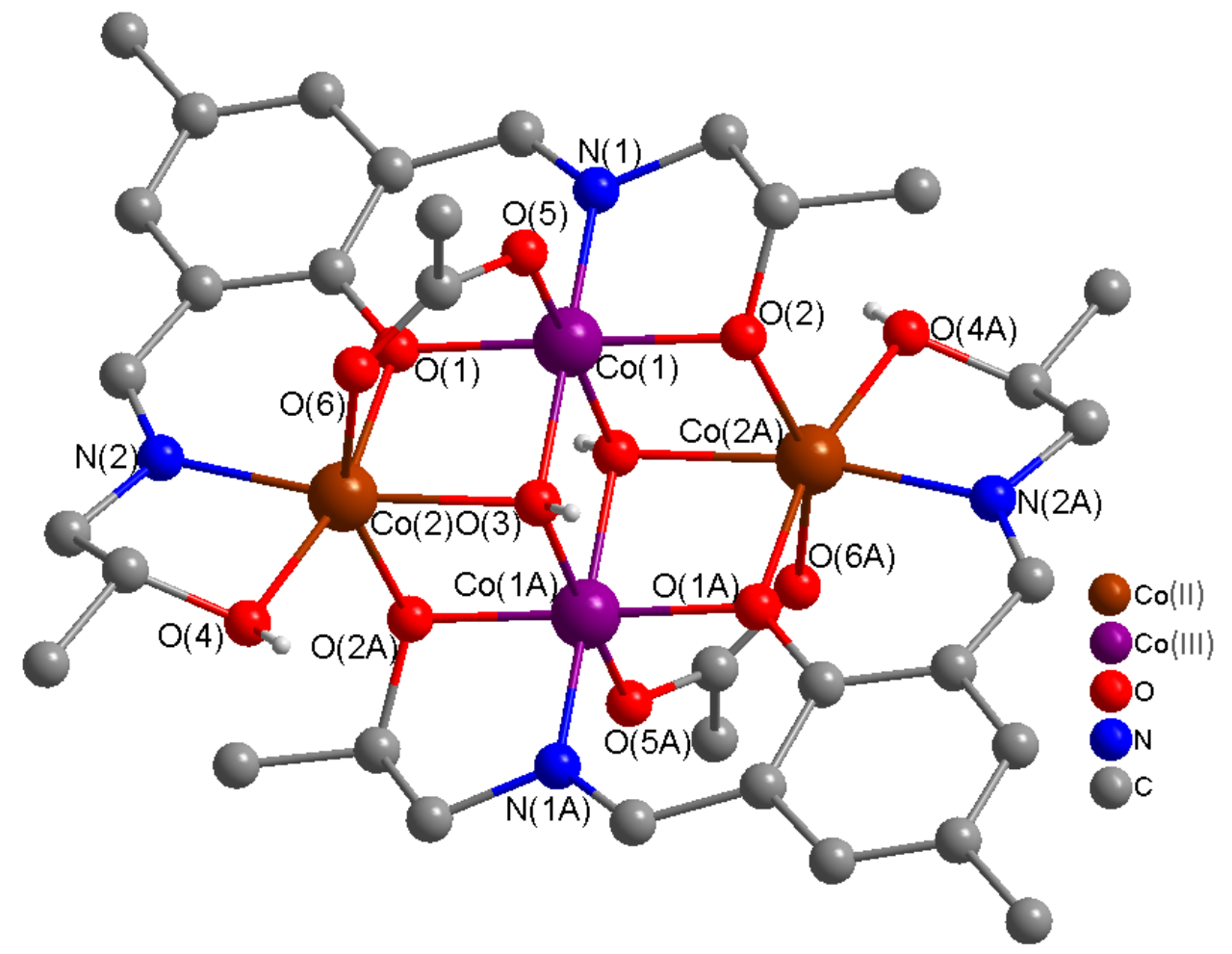

Figure 5. Molecular structure of a centrosymmetric tetranuclear cationic unit $\left[\mathrm{Co}_{2}{ }^{\mathrm{II}} \mathrm{Co}_{2}{ }^{\mathrm{III}}\left(\mathrm{HL}^{-2}\right)_{2}\left(\mu-\mathrm{CH}_{3} \mathrm{CO}_{2}\right)_{2}\left(\mu_{3-} \mathrm{OH}\right)_{2}\right]^{2+}$ in (3) with numbering of atoms in the coordination environment. $\mathrm{H}$ atoms and solvent molecules are omitted for clarity. Atoms with $\mathrm{A}$ in their labels are symmetry generated.

The oxidation state assignments for the cobalt ions in complex 3 which are color coded (Figure 5) are made using charge considerations, bond valence sums (BVS) calculations, and interatomic distances (Co-N and $\mathrm{Co}-\mathrm{O})$. Interatomic distances (Co-O and $\mathrm{Co}-\mathrm{N})$ for $\mathrm{Co}(1)$ lie in the ranges 1.891-1.927 $\AA$ and $1.873 \AA$, respectively, and those for $\mathrm{Co}(2)(\mathrm{Co}-\mathrm{O}$ and $\mathrm{Co}-\mathrm{N})$ lie in the ranges $2.000-2.131 \AA$ and $2.036 \AA$, respectively. The distances for $\mathrm{Co}(2)$ are significantly much longer than $\mathrm{Co}(1)$, clearly indicating that $\mathrm{Co}(1)$ and its symmetry related $\mathrm{Co}(1 \mathrm{~A})$ are $\mathrm{Co}^{\mathrm{III}}$ and $\mathrm{Co}(2)$ and its symmertry related $\mathrm{Co}(2 \mathrm{~A})$ are $\mathrm{Co}^{\mathrm{II}}$. The bond valence sums (BVS) calculations using bond length data from the literature [73-76] were performed on complex 3 to obtain useful and important information about the oxidation state for cobalt ions. BVS values of 3.54 and 2.22 for $\mathrm{Co}(1)$ and $\mathrm{Co}(2)$, respectively, are typical for $\mathrm{Co}(\mathrm{III})$ and Co(II) [73-76].

\subsection{3. $\left[\mathrm{Co}_{2}{ }^{\mathrm{II}} \mathrm{CO}_{2}{ }^{\mathrm{III}}\left(\mathrm{H}_{2} \mathrm{~L}^{-2}\right)_{2}\left(\mathrm{THMAM}^{-1}\right)_{2}\right]\left(\mathrm{NO}_{3}\right)_{4}$}

Aerobic reaction between DFMP and tris(hydroxymethyl)aminomethane (THMAM) in the presence of cobalt(II) nitrate and triethylamine (TEA) result in the formation of a mixed-valence tetranuclear coordination complex, $\left[\mathrm{Co}_{2}{ }^{\mathrm{II}} \mathrm{Co}_{2}{ }^{\mathrm{III}}\left(\mathrm{H}_{2} \mathrm{L1}^{2-}\right)_{2}\left(\mathrm{THMAM}^{-}\right)_{2}\right]\left(\mathrm{NO}_{3}\right)_{4}$ (4). The molecular structures of complex 4 consists of dicrete centrosymmetric mixed-valence tetranuclear cationic $\left[\mathrm{Co}_{2}{ }^{\mathrm{II}} \mathrm{Co}_{2}{ }^{\mathrm{III}}\left(\mathrm{H}_{2} \mathrm{~L}^{2-}\right)_{2}\left(\mathrm{THMAM}^{2-}\right)_{2}\right]^{4+}$ unit with two incomplete cubanes fused together (Figure 6). The bond distances and bond angles relevant to the coordination core of cobalt ions are given in Table S4. The basal plane of cobal(1) is defined by a donor set of four oxygen atoms $[\mathrm{O}(1), \mathrm{O}(2)$, $\mathrm{O}(3)$, and $\mathrm{O}(6 \mathrm{~A})$ ] from phenoxy oxygen, aldehyde oxygen, and ethanolate oxygen from $\mathrm{H}_{2} \mathrm{~L}^{2-}$, and an alkoxy $\left(\mu_{3}-\mathrm{O}\right)$ oxygen atom of THMAM. The axial positons are occupied by ethanolate oxygen $(\mathrm{O}(4 \mathrm{~A}))$ in the side arm of the ligand and an alkoxide oxygen $(\mathrm{O}(7))$ of THMAM in a slightly distorted octahedral arrangement. The basal plane of cobal(2) is defined by a donor set of three oxygen and one nitrogen atoms $\left[\mathrm{NO}_{3}\right]$, from phenoxy oxygen $(\mathrm{O}(1))$, ethanolate oxygen $(\mathrm{O}(4))$, and imino nitrogen 
(N(1)) from $\mathrm{H}_{2} \mathrm{~L}^{2-}$, and an alkoxy $\left(\mu_{3}-\mathrm{O}(3)\right)$ oxygen atom of THMAM. The axial positons are occupied by amino nitrogen $(\mathrm{N}(2))$ and alkoxide oxygen $\left(\mu_{3}-\mathrm{O}(3 \mathrm{~A})\right)$ of THMAM molecules in a slightly distorted octahedral stereochemical arrangement.

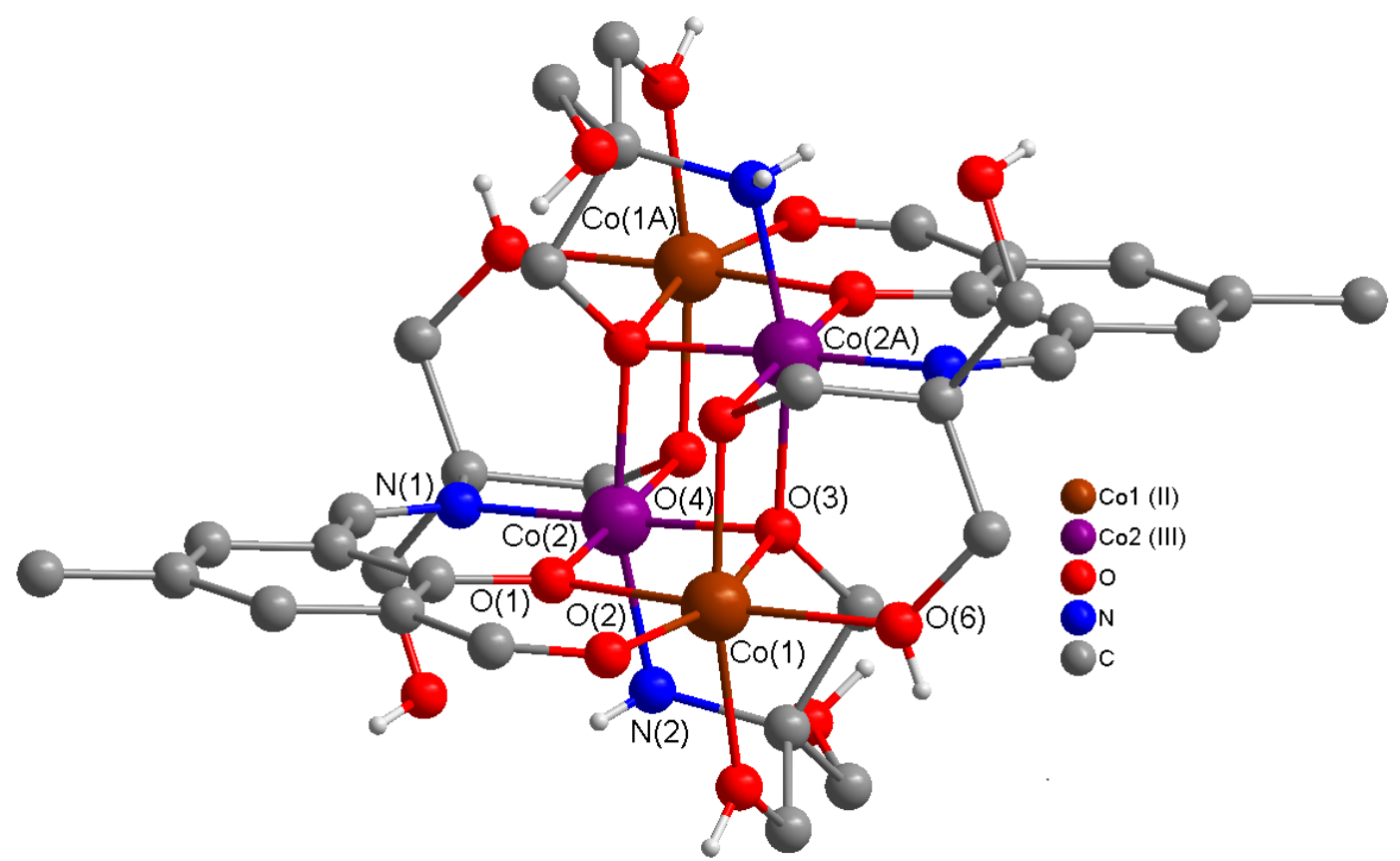

Figure 6. Molecular structure of a cationic centrosymmetric tetranuclear unit $\left[\mathrm{Co}_{2}{ }^{\mathrm{II}} \mathrm{Co}_{2}{ }^{\mathrm{III}}\left(\mathrm{H}_{2} \mathrm{L1}^{-2}\right)_{2}\left(\mathrm{THMAM}^{-1}\right)_{2}\right]^{4+}$ (4) with numbering of atoms in the coordination environment. $\mathrm{H}$ atoms and $\mathrm{NO}_{3}{ }^{-}$ions are omitted for clarity. Atoms with $\mathrm{A}$ in their labels are symmetry generated.

The oxidation state assignments for the cobalt ions are made using charge considerations, BVS calculations, and $\mathrm{Co}-\mathrm{N}$ and $\mathrm{Co}-\mathrm{O}$ interatomic distances. Interatomic distances $(\mathrm{Co}-\mathrm{O})$ for $\mathrm{Co}(1)$ lie in the range 2.014 (3)-2.118 (4) $\AA$ and those for $\mathrm{Co}(2)$ (Co-N and Co-O) lie in the ranges 1.867 (4)-1.925 (4) $\AA$ and 1.877(3)-1.977(3), respectively. The distances for $\operatorname{Co}(1)$ are significantly longer than $\operatorname{Co}(2)$, clearly indicating that $\operatorname{Co}(1)$ and $\operatorname{Co}(2)$ have oxidation state of +2 and +3 , respectively. $\operatorname{Co}(1)$ and its symmetry related $\mathrm{Co}(1 \mathrm{~A})$ and $\mathrm{Co}(2)$ and its symmertry related $\mathrm{Co}(2 \mathrm{~A})$ have been assigned $\mathrm{Co}^{\mathrm{II}}$ and $\mathrm{Co}{ }^{\mathrm{III}}$, respectively. BVS values of 2.14 and 3.64 for $\mathrm{Co}(1)$ and $\mathrm{Co}(2)$, respectively, are typical for $\mathrm{Co}(\mathrm{II})$ and $\mathrm{Co}(\mathrm{III})$ [73-76].

In 4, Schiff base ligand $\left(\mathrm{H}_{4} \mathrm{~L} 1\right)$, formed from $1+1$ condensation of DFMP and THMAM, acts in a pentadenate $\left[\mathrm{NO}_{4}\right]$ dianionic $\left(\mathrm{H}_{2} \mathrm{~L}^{2-}\right)$ capacity binding two metal centers $\left(\mathrm{CO}^{\mathrm{II}} \mathrm{Co}{ }^{\mathrm{III}}\right)$, which are linked through triply bridging alkoxy $\left(\mu_{3}-\mathrm{O}(3)\right)$ and doubly bridging phenoxy $\left(\mu-\mathrm{C}_{6} \mathrm{H}_{5} \mathrm{O}\right)$ oxygen atoms of THMAM and the Schiff base ligand, $\mathrm{H}_{2} \mathrm{L1}^{2-}$, respectively. The two dinuclear units are linked together through two triply bridging alkoxy $\left(\mu_{3}-\mathrm{O}\right)$ oxygen atoms of THMAM ligand which act as intra- and inter-dinuclear bridges and two interdinclear, doubly bridging ethanolate $(\mu-\mathrm{O})$ oxygen atoms in the side arms of the ligands $\left(\mathrm{H}_{2} \mathrm{~L}^{2-}\right)$ forming tetranuclear cationic core with non-coordinated $\mathrm{NO}_{3}{ }^{-}$ ions as counter anions in the crystal lattice which are involved in H-bonding interactions between tetranuclear units forming 2D-sheet structure.

The Cobalt(II) ions $(\mathrm{Co}(1)$ and $\mathrm{Co}(1 \mathrm{~A}))$ have a slightly distorted octahedral $\left[\mathrm{O}_{6}\right]$ arrangement with the Co-O distances ranging from 2.014 (3)-2.118 (4) $\AA$. The Cobalt(III) ions (Co(2) and Co(2A)) in the tetranuclear core exhibit a slightly distorted octahedral $\left[\mathrm{N}_{2} \mathrm{O}_{4}\right]$ environment with the Co-N distances ranging from 1.867 (4) to 1.925 (4) $\AA$ and the Co-O distances ranging from 1.877 (3) to 1.977 (3) $\AA$ (Table S4). The Co-N and Co-O distances are very similar to the distances reported for similar mixed-valence cobalt complexes with simiar Schiff base ligands [53,70,71]. The Co-Co distances in the doubly bridged dinuclear and tetranuclear units are in the range 2.9521 (9)-3.055 (1) $\AA$ which are 
slightly shorter than the distances reported in similar mixed-valence cobalt complexes [53]. There are four uncoordinated $\mathrm{NO}_{3}{ }^{-}$ions per tetranuclear unit in the lattice. In each dinuclear unit, the phenoxide bridge angle $\left(\mathrm{Co}(1)-\mathrm{O}(1)-\mathrm{Co}(2)\right.$ is $101.38(13)^{\circ}$ and the alkoxide $\left(\mu_{3}-\mathrm{O}(3)\right)$ bridge angle $(\mathrm{Co}(1)-\mathrm{O}(3)-\mathrm{Co}(2))$ is $98.58(12)^{\circ}$. The bridge angles at the doubly bridging ethanolate oxygen $(\mu-\mathrm{O}(4))(\mathrm{Co}(2)-\mathrm{O}(4)-\mathrm{Co}(1 \mathrm{~A}))$ and the triply bridging ethanoate oxygens $\left(\mu_{3}-\mathrm{O}(3)\right)(\mathrm{Co}(1)-\mathrm{O}(3)-\mathrm{Co}(2 \mathrm{~A})$ and $\mathrm{Co}(2)-\mathrm{O}(3)-\mathrm{Co}(2 \mathrm{~A}))$ which bridge the two dinuclear units in the tetranuclear core are $101.39(13)^{\circ}, 94.96(12)^{\circ}$, and $98.52(13)^{\circ}$, respectively. The solid angles at the phenoxide $\left(\mu-\mathrm{O}(1)\right.$ and ethanolate $\left(\mu_{3}-\mathrm{O}(3)\right.$, and $\left.\mu-\mathrm{O}(4)\right)$ bridges are $358.78(6)^{\circ}, 292.06(6)^{\circ}$, and $326.79(6)^{\circ}$, respectively, and are indicative of the $\mu$-planar, $\mu_{3}$-cubic, and $\mu$-pyramidal arrangements at these bridging centers similar to $\mathrm{Co}^{\mathrm{II}}$ and mixed-valenec $\left(\mathrm{Co}^{\mathrm{II}} / \mathrm{Co}^{\mathrm{III}}\right)$ complexes [53,77-85].

In 4, a symmetric network of reasonably strong, intermolecular H-bonding interactions (2.765-2.930 $\AA$ ) between oxygen atoms $(\mathrm{O}(9), \mathrm{O}(10), \mathrm{O}(11))$ of the uncoordinated $\mathrm{NO}_{3}{ }^{-}$ions and the uncoordinated protonated ethanoate oxygen $(\mathrm{O}(5))$ atom in the side arm of the ligand $\left(\mathrm{H}_{2} \mathrm{~L}^{2-}\right)(\mathrm{O}(11)-\mathrm{O}(5)=2.805 \AA)$, in one tetranuclear unit and the coordinated amino group $\left(\mathrm{NH}_{2}\right)$ $(\mathrm{O}(9)-\mathrm{N}(2)=2.930 \AA)$ and the uncoordinated hydroxy $(\mathrm{O} 8))$ of THMAM $(\mathrm{O}(10)-\mathrm{O}(8)=2.765 \AA)$ of the neighboring tetranuclear unit, direct the formation of a beautiful 2D-sheet structure (Figure 7). These H-bonding interactions seem to be responsible for the formation and the stability of complex 4, as attempts to isolate cobalt complex by reacting $\mathrm{Co}\left(\mathrm{CH}_{3} \mathrm{COOH}\right)_{2+} 4 \mathrm{H}_{2} \mathrm{O}$ with $\mathrm{H} 4 \mathrm{~L} 1$ did not succeed.

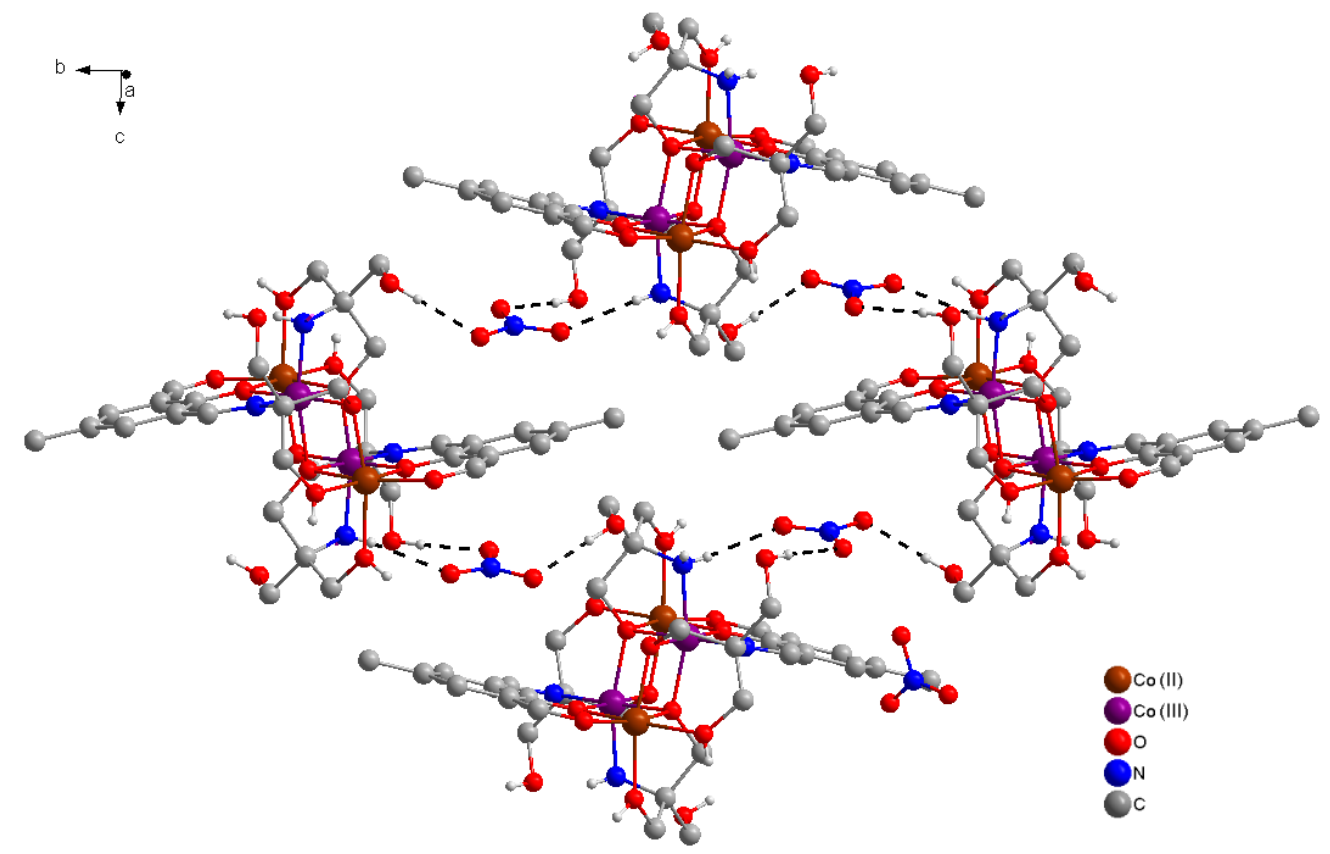

Figure 7. Perspective view of a H-bonding-directed 2D-sheet structure of 4 along the $b c$-axis.

\subsection{Magnetic Properties}

The variable temperature magnetic properties of 2 are illustrated in Figure 8 as a plot of chi.T vs $T$. The characteristic maximum at low temperature suggests intramolecular exchange, dominated by ferromagnetic coupling as reported in ferromagnetically coupled tetranuclear Cobalt(II) complexes involving $\mu_{1,1}-\mathrm{N}_{3}$ and $\mu$-O bridges [86] or pseudo halide bridges [87]. The RT moment per metal is $5.46 \mathrm{muB}$, which is in the upper range for high spin Co(II). The small rise on lowering temperature is the result of spin orbital coupling effects. While the Co-O-Co angle of $100.4^{\circ}$ is consistent with antiferromagnetic exchange in general, the small Co-N-Co angle $\left(93.9^{\circ}\right)$ is in the realm expected for ferromagnetic exchange. In this case, the ferromagnetic component appears to dominate. Fitting of the 
exchange data to an appropriate Hamiltonian did not give a satisfactory fit, as anticipated for Co(II), due to spin-orbit effects.

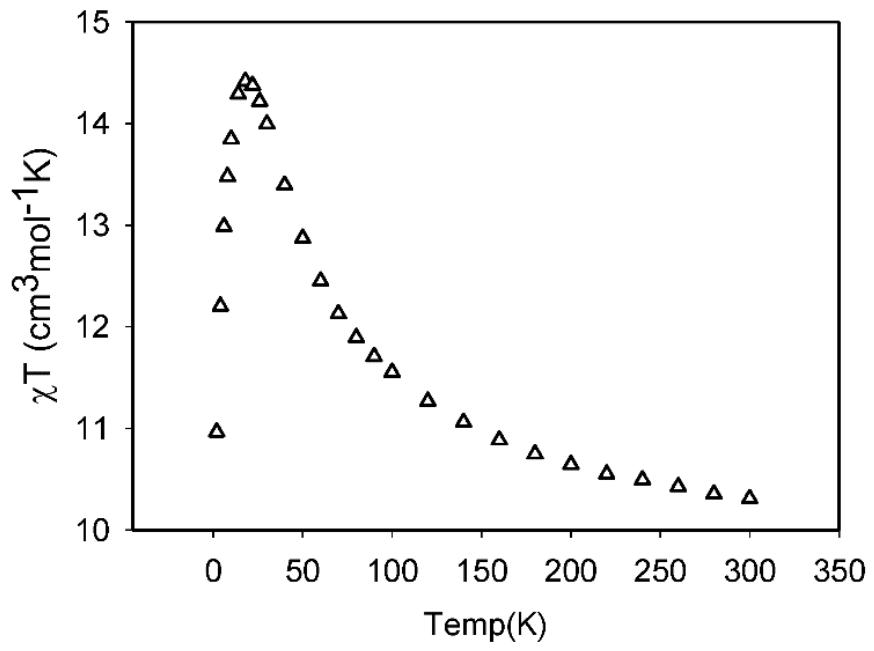

Figure 8. chi.T vs T plot of complex 2.

\subsection{IR and $U V-V i s$ Spectroscopy}

In the IR spectra of $\mathbf{1}$ and $\mathbf{2}$, which have terminal azide $\left(\mathrm{N}_{3}\right)$ ions and intra and inter-dimer EO $\left(\mu-1,1-\mathrm{N}_{3}\right.$ or $\left.\mu_{3}-1,1,1-\mathrm{N}_{3}\right)$ bridging azide ions, one band is observed at $2227(1) / 2084 \mathrm{~cm}^{-1}$, typical for $v_{\text {as }}$ $\left(\mathrm{N}_{3}\right)$. In the IR spectra of 1-4, a band in the region $3445-3333 \mathrm{~cm}^{-1}$ and one or two bands in the region 1651-1637 $\mathrm{cm}^{-1}$ are due to $v(\mathrm{OH})\left(\mathrm{H}_{2} \mathrm{O}\right.$ and $\left.\mathrm{CH}_{3} \mathrm{OH}\right)$ and $v(\mathrm{C}=\mathrm{N})$ of coordinated imine, respectively. In the IR spectra of 1, three bands in the regions at 3294, 3243, $3142 \mathrm{~cm}^{-1}$, and in 4 , one band at $3179 \mathrm{~cm}^{-1}$ are due to $\left(v\left(\mathrm{NH}_{2}\right)\right.$ of the coordinated amino group of $\mathrm{AP}^{-1}$ and THMAM${ }^{-1}$, respectively.

In the UV-Vis spectra of 1-2 compounds, a strong band at 430-390 $\mathrm{nm}$ and a high energy band or shoulder at 320-270 $\mathrm{nm}$ are assigned to metal-azide and metal-ligand charge transfer transitions. In the visible spectra of the 1-4 complexes, one to three broad bands/shoulders in the region $680-525 \mathrm{~nm}$ are due to $\mathrm{d}-\mathrm{d}$ transitions.

\section{Conclusions}

In this publication, we have reported one-pot self-assembly and structural characterization of four new Cobalt(III) (1), Cobalt(II) (2), and mixed-valence (Co $\mathrm{CI}^{\mathrm{II}} \mathrm{Co}^{\mathrm{III}}$ ) (3 and 4) complexes with two Schiff base ligands: $\mathrm{H}_{3} \mathrm{~L}$ (double Schiff base ligand) and $\mathrm{H}_{4} \mathrm{~L} 1$ (single Schiff base ligand), with a very high degree of conformational flexibility and potential to coordinate in a convergent and a divergent fashions. In complexes $\mathbf{2}$ and $\mathbf{4}, \mathrm{H}$-bonding directs the polymerization of neutral tetranuclear Cobalt(II) units $\left[\mathrm{Co}_{4}\left(\mathrm{H}_{2} \mathrm{~L}^{-1}\right)_{2}\left(\mu_{3}-1,1,1-\mathrm{N}_{3}\right)_{2}\left(\mu-1,1-\mathrm{N}_{3}\right)_{2} \mathrm{Cl}_{2}\left(\mathrm{CH}_{3} \mathrm{OH}\right)_{2}\right] \cdot 4 \mathrm{CH}_{3} \mathrm{OH}$ (2) and tetranuclear mixed-valence cationic units $\left[\mathrm{Co}_{2}{ }^{\mathrm{II}} \mathrm{Co}_{2}{ }^{\mathrm{III}}\left(\mathrm{H}_{2} \mathrm{~L}^{-2}\right)_{2}\left(\mathrm{THMAM}^{-1}\right)_{2}\right]\left(\mathrm{NO}_{3}\right)_{4}(4)$ to $1 \mathrm{D}$-single chains and 2D-sheet structures, respectively. The uncoordinated/coordinated protonated hydroxy groups in the side arms of the ligands are involved in the intramolecular and intermolecular H-bonding interactions with uncoordinated/coordinated methanol molecules $/ \mathrm{NO}_{3}{ }^{-}$ions to generate polymeric complexes with 1D-single chains (2) and 2D-sheet (4) structures. Depending upon the stereochemical requirements of Cobalt(II)/Cobalt(III) centers in dinuclear or tetranuclear units, the azide ions act as intradimer/interdimer EO double $\left(\mu-1,1-\mathrm{N}_{3}\right)$ or triple bridges $\left(\mu_{3}-1,1,1-\mathrm{N}_{3}\right)$, carboxylate as a double bridge, hydroxide ion as a triple bridge $\left(\mu_{3}-1,1,1-\mathrm{OH}\right)$. In these complexes, $\mathrm{H}_{3} \mathrm{~L}$ acts as a tridentate $\left(\mathrm{NO}_{2}\right)$ monoanionic (1), tetradentate $\left(\mathrm{N}_{2} \mathrm{O}_{2}\right)$ monoanionic (2), and pentadentate $\left(\mathrm{N}_{2} \mathrm{O}_{3}\right)$ dianionic ligand. In complex $4, \mathrm{H}_{4} \mathrm{~L} 1$ behaves as a pentadentate $\left(\mathrm{NO}_{4}\right)$ dianionic ligand. Further studies to procure coordination clusters of $3 \mathrm{~d}, 4 \mathrm{f}$, and mixed metal $(3 \mathrm{~d}-4 \mathrm{f})$ of double Schiff base $\left(\mathrm{H}_{7} \mathrm{~L} 3\right)$ and other similar ligands are in progress. 
Supplementary Materials: The following are available online at http://www.mdpi.com/1996-1944/13/23/5425/s1, Table S1-S4: combined Co checkcif report, combined Co structures 2019.

Author Contributions: Conceptualization and methodology, S.S.T. and S.D.B.; formal analysis, S.S.T. and S.D.B.; investigation, N.P., E.C.W., R.T., L.K.T., S.D.B. and S.S.T.; data curation, S.S.T. and S.D.B.; writing-original draft preparation, S.S.T.; writing-review and editing, S.S.T. and S.D.B.; visualization, S.S.T. and S.D.B.; supervision, S.S.T. and S.D.B.; project administration, S.S.T.; funding acquisition, S.S.T. All authors have read and agreed to the published version of the manuscript.

Funding: This research received no external funding.

Acknowledgments: Kent State University at Salem is thanked for the financial support and SST thanks Mahinda Gangoda (KSU) for the assistance with spectroscopic and analytical studies.

Conflicts of Interest: The authors declare no conflict of interest.

\section{References}

1. Uhlenheuer, D.A.; Petkau, K.; Brunsreld, L. Combining supramolecular chemistry with biology. Chem. Soc. Rev. 2010, 39, 2817-2826. [CrossRef] [PubMed]

2. Davis, J.T.; Spada, G.P. Supramolecular architectures generated by self-assembly of guanosine derivatives. Chem. Soc. Rev. 2007, 36, 296-313. [CrossRef] [PubMed]

3. Younjin, M.; Mustafa, A.; Kai, K.; Yuval, G.; Jacob, I. The role of interparticle and external forces in nanoparticle assembly. Nat. Mater. 2008, 7, 527-538.

4. Lehn, J.-M. Supramolecular Chemistry-Scope and perspectives molecules, supermolecules, and molecular devices (Nobel Lecture). Angew. Chem. Int. Ed. 1988, 27, 89-112. [CrossRef]

5. Lohmeijer, B.G.G.; Schubert, U.S. Supramolecular engineering with macromolecules: An alternative concept for block copolymers. Angew. Chem. Int. Ed. 2002, 41, 3825-3829. [CrossRef]

6. Lehn, J.-M. Supramolecular Chemistry: Concepts and Perspectives; VCH: Weihneim, Germany, 1995.

7. Stupp, S.I.; Palmer, L.C. Supramolecular chemistry and self-assembly in organic materials design. Chem. Mater. 2014, 26, 507-518. [CrossRef]

8. Nicolaou, K.C.; Vourloumis, D.; Winssinger, N.; Baran, P.S. The art and science of total synthesis at the dawn of the twenty-first century. Angew. Chem. Int. Ed. 2000, 39, 44-122. [CrossRef]

9. He, Z.; Jiang, W.; Schalley, C.A. Integrative self-sorting: A versatile strategy for the construction of complex supramolecular architecture. Chem. Soc. Rev. 2015, 44, 779-789. [CrossRef]

10. Stang, P.J.; Olenyuk, B. Self-assembly, symmetry, and molecular architecture: Coordination as the motif in the rational design of supramolecular metallacyclic polygons and polyhedral. Acc. Chem. Res. 1997, 30, 502-518. [CrossRef]

11. Glotzer, S.C. Some assembly required. Science 2004, 306, 419-420. [CrossRef]

12. Boles, M.A.; Engel, M.; Talapin, D.V. Self-assembly of colloidal nanocrystals: From intricate structures to functional materials. Chem. Rev. 2016, 116, 11220-11289. [CrossRef] [PubMed]

13. Cook, T.R.; Zheng, Y.-R.; Stang, P.J. Metal-organic frameworks and self-assembled supramolecular coordination complexes: Comparing and contrasting the design, synthesis, and functionality of metal-organic materials. Chem. Rev. 2013, 113, 734-777. [CrossRef] [PubMed]

14. Tanaka, S.; Tsurugi, H.; Mashima, K. Supramolecular assemblies of multi-nuclear transition metal complexes: Synthesis and redox properties. Coord. Chem. Rev. 2014, 265, 38-51. [CrossRef]

15. Dalgarno, S.J.; Power, N.P.; Atwood, J.L. Metallo-supramolecular capsules. Coord. Chem. Rev. 2008, 252, 825-841. [CrossRef]

16. Koshevoy, I.O.; Koskinen, L.; Haukka, M.; Tunik, S.P.; Serdobintsev, P.Y.; Melnikov, A.S.; Pakkanen, T.A. Self-assembly of supramolecular luminescent AuI-CuI complexes: "Wrapping" an $\mathrm{Au}_{6} \mathrm{Cu}_{6}$ cluster in a $\left.\left[\mathrm{Au}_{3} \text { (diphosphine) }\right)_{3}\right]^{3+}$ "belt". Angew. Chem. Int. Ed. 2008, 47, 3942-3945. [CrossRef]

17. Molecular Self-Assembly Organic Versus Inorganic Approaches; Fujita, M. (Ed.) Springer: Berlin/Heidelberg, Germany, 2003.

18. Caulder, D.L.; Powers, R.E.; Parac, T.N.; Raymon, K.N. The Self-assembly of a predesigned tetrahedral M4L6 supramolecular cluster. Angew. Chem. Int. Ed. 1998, 37, 1840-1843. [CrossRef]

19. Zheng, Z. Ligand-controlled self-assembly of polynuclear lanthanide-oxo/hydroxo complexes: From synthetic serendipity to rational supramolecular design. Chem. Commun. 2001, 2521-2529. [CrossRef] 
20. Johnson, D.W.; Xu, J.; Saalfrank, R.W.; Raymond, K.N. Self-assembly of a three-dimensional $\left[\mathrm{Ga}_{6}\left(\mathrm{~L}^{2}\right)_{6}\right]$ metal-ligand "cylinder". Anew. Chem. Int. Ed. 1999, 38, 2882-2885. [CrossRef]

21. Saalfrank, R.W.; Glaser, H.; Demleitner, B.; Hampel, F.; Chowdhary, M.M.; Schunemann, V.; Trautwein, A.X.; Vaughan, G.B.M.; Yeh, R.; Davis, A.V.; et al. Self-assembly of tetrahedral and trigonal antiprismatic clusters $\left[\mathrm{Fe}_{4}\left(\mathrm{~L}^{4}\right)_{4}\right]$ and $\left[\mathrm{Fe}_{6}\left(\mathrm{~L}^{5}\right)_{6}\right]$ on the basis of trigonal tris-bidentate chelators. Chem. Eur. J. 2002, 8, $493-497$. [CrossRef]

22. Templated Organic Synthesis; Diederich, F.; Stang, P.J. (Eds.) Wiley-VCH: Weinheim, Germany, 2000.

23. Tandon, S.S.; Bunge, S.D.; Toth, S.A.; Sanchiz, J.; Thompson, L.K.; Shelley, J.T. Antiferromagnetically coupled dimeric dodecacopper supramolecular architectures of macrocyclic ligands with a symmetrical $\mu_{6}-\mathrm{BO}_{3}{ }^{3-}$ central moiety. Inorg. Chem. 2015, 54, 6873-6884. [CrossRef]

24. Wilkinson, M.J.; Van Leeuwen, P.W.; Reek, J.N. New directions in supramolecular transition metal catalysis. Org. Biomol. Chem. 2005, 3, 2371-2383. [CrossRef] [PubMed]

25. Van Leeuwen, P.W.N.M. Homogeneous Catalysis; Kluwer Academic Publishers: Dordrecht, The Netherlands, 2004.

26. Sivasubramaniam, V.K.; Ganesan, M.; Rajagopal, S.; Ramaraj, R. Iron (III)-salen complexes as enzyme models: Mechanistic study of oxo (salen) iron complexes oxygenation of organic sulfides. J. Org. Chem. 2002, 67, 1506-1514. [CrossRef] [PubMed]

27. Rizzarelli, E.; Vecchio, G. Metal complexes of functionalized cyclodextrins as enzyme models and chiral receptors. Coord. Chem. Rev. 1999, 188, 343-364. [CrossRef]

28. Van den Benken, E.K.; Feringu, B.L. Bimetallic catalysis by late transition metal complexes. Tetrahedron 1998, 54, 12985-13011. [CrossRef]

29. Karlin, K.D. Progress in Inorganic Chemistry; Wiley: New York, NY, USA, 2007; Volume 41.

30. Plass, W. Structural variety and magnetic properties of polynuclear assemblies based on 2-aminoglucose and tritopic triaminoguanidine ligands. Coord. Chem. Rev. 2009, 253, 2286-2295. [CrossRef]

31. Burkhard, A.; Spielberg, E.T.; Simon, S.; Gorls, H.; Buchholz, A.; Plass, W.A. Facile, modular, scalable route to novel helical dications. Chem. Eur. J. 2009, 15, 1261-1271.

32. Ribas, R.; Escuer, A.; Monfort, M.; Vicente, R.; Cortes, R.; Lezama, L.; Rojo, T. Polynuclear Ni ${ }^{\mathrm{II}}$ and Mn MI azido bridging complexes. Structural trends and magnetic behavior. Coord. Chem. Rev. 1999, 193-195, 1027-1068. [CrossRef]

33. Dul, M.C.; Pardo, E.; Lescouëzec, R.; Journaux, Y.; Ferrando-Soria, J.; Ruiz-García, R.; Cano, J.; Julve, M.; Lloret, F.; Cangussu, D.; et al. Supramolecular coordination chemistry of aromatic polyoxalamide ligands: A metallosupramolecular approach toward functional magnetic materials. Coord. Chem. Rev. 2010, 254, 2281-2296. [CrossRef]

34. Christou, G.; Gatteschi, D.; Hendrickson, D.N.; Sessoli, R. Single-molecule magnets. MRS Bull. 2000, 25, 66-71. [CrossRef]

35. Nesterov, D.S.; Nesterova, O.V. Polynuclear cobalt complexes as catalysts for light-drivenwater oxidation: A aeview of recent advances. Catalysts 2018, 8, 602. [CrossRef]

36. Pal, A.; Li, C.; Hanan, G.S.; Colman, E.Z. Blue-Emissive Cobalt (III) Complexes and Their Use in the Photocatalytic Trifluoromethylation of Polycyclic Aromatic Hydrocarbons. Angew. Chem. 2018, 130, 8159-8163.

37. McKee, V.; Tandon, S.S. X-Ray crystal structure and some properties of a tetranuclear, mixed-valence manganese complex of a macrocyclic ligand. J. Chem. Soc. Chem. Commun. 1988, 1334-1336. [CrossRef]

38. McKee, V.; Tandon, S.S. The x-ray crystal structure and some properties of a planar tetracopper(II) macrocyclic complex containing a $\mu_{4}$-hydroxo bridge. J. Chem. Soc. Chem. Commun. 1988, 385-387. [CrossRef]

39. McKee, V.; Tandon, S.S. An Octacopper(II) complex with $\mu_{5}$ - and tripodlike perchlorate ligands: Formation and X-ray structure of the $\left[\mathrm{Cu}_{4}(\mathrm{~L}) 0\left(\mathrm{CIO}_{4}\right)\right]_{2}\left(\mathrm{ClO}_{4}\right)_{2} \cdot 2 \mathrm{H}_{2} \mathrm{O}$ dimer. Inorg. Chem. 1989, 28, 2901-2902. [CrossRef]

40. Tandon, S.S.; McKee, V. Lead(II) and barium(II) complexes of a potentially octadentate macrocyclic ligand $\left(\mathrm{H}_{4} \mathrm{~L}\right)$, capable of providing endogenous alkoxy and phenoxy bridges. The X-ray crystal structures of $\left[\mathrm{Pb}\left(\mathrm{H}_{4} \mathrm{~L}\right)\right]\left(\mathrm{ClO}_{4}\right)_{2},\left[\mathrm{~Pb}_{2}\left(\mathrm{H}_{2} \mathrm{~L}\right)\right]\left(\mathrm{ClO}_{4}\right)_{2}$ and $\left[\mathrm{H}_{6} \mathrm{~L}\left(\mathrm{H}_{2} \mathrm{O}\right)_{2}\right]\left(\mathrm{ClO}_{4}\right)_{2}$. J. Chem. Soc. Dalton Trans 1989, $19-24$. [CrossRef] 
41. Downard, J.; McKee, V.; Tandon, S.S. Binuclear manganese(II) and nickel(II) complexes of a potentially octadentate macrocyclic ligand $\left(\mathrm{H}_{4} \mathrm{~L}\right)$, capable of providing endogenous alkoxy and phenoxy bridges. The x-ray crystal structures of $\left[\mathrm{Mn}_{2}\left(\mathrm{H}_{2} \mathrm{~L}\right)\left(\mathrm{CH}_{3} \mathrm{COO}\right)_{2}\right] \cdot \mathrm{CH}_{3} \mathrm{OH}$ and $\left[\mathrm{Ni}_{2}\left(\mathrm{H}_{2} \mathrm{~L}\right) \mathrm{Cl}_{2}\left(\mathrm{H}_{2} \mathrm{O}\right)_{2}\right]$. Inorg. Chim. Acta 1990, 173, 181-190. [CrossRef]

42. McKee, V.; Tandon, S.S. Synthesis and characterization of a series of tetra-and octa-copper (II) complexes with macrocyclic ligands. J. Chem. Soc. Dalton Trans. 1991, 221-230. [CrossRef]

43. Tandon, S.S.; Thompson, L.K.; Bridson, J.N.; McKee, V.; Downard, A.J. Dinuclear copper(II) and polymeric tetranuclear copper(II) and copper(II)-copper(I) complexes of macrocyclic ligands capable of forming endogenous alkoxide and phenoxide bridges. structural, magnetic, and electrochemical studies. Inorg. Chem. 1992, 31, 4635-4642. [CrossRef]

44. Tandon, S.S.; Thompson, L.K.; Bridson, J.N. A Novel antiferromagnetically coupled, dimeric, dodecanuclear copper(II) complex involving two macrocyclic ligands each with a 'benzene-like' arrangement of six copper centres. J. Chem. Soc. Chem. Commun. 1992, 911-913. [CrossRef]

45. Tandon, S.S.; Thompson, L.K.; Bridson, J.N.; Bubenik, M. Synthetic, structural and magnetic properties of mononuclear, dinuclear and tetranuclear copper(II) complexes of a 17-membered macrocyclic ligand (HM3), capable of forming endogenous phenoxide and pyridazino bridges. X-ray crystal structure of $\left[\mathrm{Cu}_{2}(\mathrm{M} 3)\left(\mu_{2}-\mathrm{OMe}\right)\left(\mathrm{NO}_{3}\right)_{2}\right],\left[\mathrm{Cu}_{4}(\mathrm{M} 3)_{2}\left(\mu_{3}-\mathrm{OMe}\right)_{2}\left(\mu_{2}-\mathrm{Cl}\right)_{2} \mathrm{Cl}_{2}\right],\left[\mathrm{Cu}_{4}(\mathrm{M} 3)_{2}\left(\mu_{3}-\mathrm{OEt}\right)_{2}\left(\mu_{2}-\mathrm{N}_{3}\right)_{2}\left(\mathrm{~N}_{3}\right)_{2}\right] .(\mathrm{MeOH})$, $\left[\mathrm{Cu}_{4}(\mathrm{M} 3)\left(\mu_{3}-\mathrm{Ome}\right)_{2}(\mathrm{NCS})_{4}\right](\mathrm{DMF})$ and $\left[\mathrm{Cu}(\mathrm{HM} 3)(\mathrm{NCS})_{2}\right]$. Inorg. Chem. 1993, 32, 4621-4631.

46. Chen, L.; Thompson, L.K.; Tandon, S.S.; Bridson, J.N. Synthetic, structural, and spectroscopic studies on copper(II), copper(I), and silver(I) complexes of a series of pyridazinophane and phthalazinophane macrocycles. Unusual extended metallocyclic structures. Inorg. Chem. 1993, 32, 4063-4068. [CrossRef]

47. Tandon, S.S.; Thompson, L.K.; Bridson, J.N. Dinuclear copper(II) and mixed-valence copper(II)-copper(I) complexes of 34-membered macrocyclic ligands $\left(\mathrm{H}_{2} \mathrm{M} 1, \mathrm{H}_{2} \mathrm{M} 2\right)$ capable of forming endogenous phenolate and pyridazino bridges. X-ray crystal structures of the dinuclear copper(II) complexes $\left[\mathrm{Cu}_{2} \mathrm{M}_{1}\right]\left[\mathrm{BF}_{4}\right]_{2} \cdot \mathrm{H}_{2} \mathrm{O}$ and $\left[\mathrm{Cu}_{2} \mathrm{M} 2\right]\left[\mathrm{BF}_{4}\right]_{2} \cdot \mathrm{CH}_{3} \mathrm{OH}$, which exhibit a remarkable ligand twist. Inorg. Chem. 1993, 32, 32-39.

48. Tandon, S.S.; Thompson, L.K.; Bridson, J.N.; Benelli, C. Hexanuclear and dodecanuclear macrocyclic copper (II) and nickel (II) complexes with almost planar" benzene-like" metal arrays. Inorg. Chem. 1995, 34, 5507-5515. [CrossRef]

49. Thompson, L.K.; Tandon, S.S.; Bridson, J.N.; Park, M.K. Magnetostructural correlations in bis( $\mu 2$-phenoxide)-bridged macrocyclic dinuclear copper(II) complexes. Influence of electron-withdrawing substituents on exchange coupling. Inorg. Chem. 1996, 35, 3117-3125. [CrossRef]

50. McCrea, J.; McKee, V.; Metcalfe, T.; Tandon, S.S.; Wikaira, J. Geometric control of redox level in tetranuclear manganese and cobalt systems. Inorg. Chim. Acta. 2000, 297, 220-230. [CrossRef]

51. Tandon, S.S.; Bunge, S.D.; Thompson, L.K. A tetradecanuclear copper dimeric macrocyclic complex with a body-centred heptanuclear core-structure and magnetism. Chem. Commun. 2007, 798-800. [CrossRef]

52. Tandon, S.S.; Bunge, S.D.; Patel, N.; Thompson, L.K. The synthesis, structure, and magnetic properties of a novel copper(II) cluster with H-bonding directed 3D-structure comprised of interconnecteddouble-stranded ladders. Inorg. Chem. Commun. 2009, 12, 1077-1080. [CrossRef]

53. Tandon, S.S.; Bunge, S.D.; Rakosi, R.; Xu, Z.; Thompson, L.K. Self-assembly of mixed-valence Co(II/III) and $\mathrm{Ni}(\mathrm{II})$ clusters: Azide-bridged 1D single chain coordination polymers comprised of tetranuclear units, tetranuclear Co(II/III) complexes, ferromagnetically coupled azide-bridged tetranuclear, and hexanuclear $\mathrm{Ni}(\mathrm{II})$ complexes: Synthesis, structural, and magnetic propertie. Dalton Trans. 2009, 6536-6551. [CrossRef]

54. Tandon, S.S.; Bunge, S.D.; Motry, D.; Costa, J.S.; Aromí, G.; Reedijk, J.; Thompson, L.K. Copper coordination polymers based on single-chain or sheet structures involving dinuclear and tetranuclear copper(II) units: Synthesis, structures, and magnetostructural correlations. Inorg. Chem. 2009, 48, 4873-4881. [CrossRef]

55. Tandon, S.S.; Bunge, S.D.; Sanchiz, J.; Thompson, L.K. Structures and magnetic properties of an antiferromagnetically coupled polymeric copper(II) complex and ferromagnetically coupled hexanuclear nickel(II) clusters. Inorg. Chem. 2012, 51, 3270-3282. [CrossRef]

56. Tandon, S.S.; Bunge, S.D.; Patel, N.; Sanchiz, J. H-bonding directed formation of 1D-single chains, 2D-sheets, and 3Dstructures in magnetically coupled tetranuclear nickel(II) complexes with incomplete double cubane core. Polyhedron 2017, 123, 361-375. [CrossRef]

57. Escuer, A.; Aromi, G. Azide as a bridging ligand and magnetic coupler in transition metal clusters. Eur. J. Inorg. Chem. 2006, 4721-4736. [CrossRef] 
58. Ferbinteanu, M.; Miyasaka, H.; Wernsdorfer, W.; Nakata, K.; Sugiura, K.; Yamashita, M.; Coulon, C.; Clerac, R. Single-chain magnet $\left(\mathrm{NEt}_{4}\right)\left[\mathrm{Mn}_{2}(5-\mathrm{MeOsalen})_{2} \mathrm{Fe}(\mathrm{CN})_{6}\right]$ made of $\mathrm{Mn}^{\mathrm{III}}-\mathrm{Fe}^{\mathrm{III}}-\mathrm{Mn}^{\mathrm{III}}$ trinuclear single-molecule magnet with an ST ) 9/2 spin ground state. J. Am. Chem. Soc. 2005, 127, 3090-3099. [CrossRef] [PubMed]

59. Massoud, S.S.; Mautner, F.A.; Vicente, R.; Gallo, A.A.; Ducasse, E. Dinuclear and polynuclear bridged azido-nickel (II) complexes: Synthesis, structure determination, and magnetic properties. Eur. J. Inorg. Chem. 2007, 1091-1102. [CrossRef]

60. Tasiopoulos, A.J.; Vinslava, A.; Wernsdorfer, W.; Abboud, K.A.; Christou, G. Giant single-molecule magnets: A $\{$ Mn84 $\}$ torus and its supramolecular nanotubes. Angew. Chem. Int. Ed. 2004, 43, 2117-2121. [CrossRef] [PubMed]

61. Chakov, N.E.; Wernsdorfer, W.; Abboud, K.A.; Christou, G. Mixed-valence Mn ${ }^{\mathrm{III}} \mathrm{Mn}^{\mathrm{IV}}$ clusters $\left[\mathrm{Mn}_{7} \mathrm{O}_{8}\left(\mathrm{O}_{2} \mathrm{SePh}\right)_{8}\left(\mathrm{O}_{2} \mathrm{CMe}\right)\left(\mathrm{H}_{2} \mathrm{O}\right)\right]$ and $\left[\mathrm{Mn}_{7} \mathrm{O}_{8}\left(\mathrm{O}_{2} \mathrm{SePh}_{9}\left(\mathrm{H}_{2} \mathrm{O}\right)\right]\right.$ : Single-chain magnets exhibiting quantum tunneling of magnetization. Inorg. Chem. 2004, 43, 5919-5930. [CrossRef]

62. Manson, J.L.; Kmety, C.R.; Huang, Q.-H.; Lynn, J.W.; Bendele, G.M.; Pagola, S.; Stephens, P.W.; Liable-Sands, L.M.; Rheingold, A.L.; Epstein, A.J.; et al. Structure and magnetic ordering of MII[N(CN)2]2 (M) Co, Ni). Chem. Mater. 1998, 10, 2552-2560. [CrossRef]

63. Ullman, F.; Brittner, K. Ther die herstellung von oxyuvitinaldehyd aue p-kresol. Chem. Ber. 1909, 42, $2539-2549$. [CrossRef]

64. APEX3, Bruker AXS, Inc. Analytical X-ray Systems; Bruker AXS, Inc.: Madison, WI, USA, 2018.

65. Bruker AXS, Inc. Analytical X-ray Systems; SAINT Version 6.45A; Bruker AXS, Inc.: Madison, WI, USA, 2003.

66. Sheldrick, G.M. SHELXT - Integrated space-group and crystal-structure determination. Acta Cryst. 2015, A71, 3-8. [CrossRef]

67. Bruker AXS, Inc. Analytical X-ray Systems; SHELXTL V6.12; Bruker AXS, Inc.: Madison, WI, USA, 2002.

68. Dolomanov, O.V.; Bourhis, L.J.; Gildea, R.J.; Howard, J.A.K.; Puschmann, H. OLEX2: A complete structure solution, refinement and analysis program. J. Appl. Cryst. 2009, 42, 339-341. [CrossRef]

69. Tandon, S.S.; Bunge, S.D.; Patel, N.; Wang, E.; Thompson, L.K. Self-assembly of antiferromagnetically coupled copper(II) supramolecular architectures with diverse structural complexities. Molecules 2020, 25, 5549. [CrossRef]

70. Shiga, T.; Maruyama, K.; Han, L.Q.; Oshio, H. Structure and magnetic property of an octadecanuclear Cu(II) complex. Chem. Lett. 2005, 34, 1648-1649. [CrossRef]

71. Yamashita, S.; Shiga, T.; Kurashina, M.; Nihei, M.; Nojjiri, H.; Sawa, H.; Kakiuchi, T.; Oshio, H. Manganese(III,IV) and manganese(III) oxide clusters trapped by copper(II) complexes. Inorg. Chem. 2007, 46, 3810-3812. [CrossRef] [PubMed]

72. Mandal, D.; Bertolasi, V.; Ribas-Arino, J.; Aromi, G.; Ray, D. Self-assembly of an azido-bridged [NiII ${ }_{6}$ ] cluster featuring four fused defective cubanes. Inorg. Chem.Commun. 2008, 47, 3465-3467. [CrossRef] [PubMed]

73. Palenik, G.J. Bond valence sums in coordination chemistry using oxidation state independent R0 values. Inorg. Chem. 1997, 36, 122. [CrossRef]

74. Thorp, H.H. Bond valence sum analysis of metal-ligand bond lengths in metalloenzymes and model complexes. Inorg. Chem. 1992, 31, 1585-1588. [CrossRef]

75. Liu, W.; Thorp, H.H. Bond valence sum analysis of metal-ligand bond lengths in metalloenzymes and model complexes. 2. Refined distances and other enzymes. Inorg. Chem. 1993, 32, 4102-4105. [CrossRef]

76. Brown, I.D.; Altermatt, D. Bond-valence parameters obtained from a systematic analysis of the inorganic crystal structure database. Acta Cryst. 1985, B41, 244-247. [CrossRef]

77. Mandal, D.; Ray, D. Self-assembly of a Co4 ${ }^{\mathrm{III}}$ face-shared partial double cubane supported by alkoxo terminal and bridging ligands. Inorg. Chem. Commun. 2007, 10, 1202-1205. [CrossRef]

78. Alley, K.G.; Bircher, R.; Waldmann, O.; Ochsenbein, S.T.; Gudel, H.U.; Moubaraki, B.; Murray, K.S.; Fernandez-Alonso, F.; Abrahams, B.F.; Boskovic, C. Mixed-valent cobalt spin clusters: A hexanuclear complex and a one-dimensional coordination polymer comprised of alternating hepta-and mononuclear fragments. Inorg. Chem. 2006, 45, 8950-8957. [CrossRef]

79. Abedin, T.S.M.; Thompson, L.K.; Miller, D. An octanuclear $\left[\mathrm{Co}(\mathrm{II})_{2}-\mathrm{Co}(\mathrm{III})_{2}\right]_{2}$ interlocked grid-example of an inorganic [2] catenane. Chem. Commun. 2005, 5512-5514. [CrossRef] [PubMed]

80. Aromi, G.; Batsanov, A.S.; Christian, P.; Helliwell, M.; Parkin, A.; Parsons, S.; Smith, A.A.; Timco, G.A.; Winpenny, R.E.P. Synthetic and structural studies of cobalt- pivalate complexes. Chem. Eur. J. 2003, 9, 5142-5161. [CrossRef] [PubMed] 
81. Ma, X.-F.; Wang, Z.; Chen, X.-L.; Kurmoo, M.; Zeng, M.-H. Ligand effect on the single-molecule magnetism of tetranuclear Co(II) cubane. Inorg. Chem. 2017, 56, 15178-15186. [CrossRef] [PubMed]

82. Nemec, I.; Herchel, R.; Machata, M.; Travnicek, Z. Tetranuclear Ni(II) and Co(II) Schiff-base complexes with an $\mathrm{M}_{4} \mathrm{O}_{6}$ defective dicubane-like core: Zero-field SMM behavior in the cobalt analogue. New J. Chem. 2017, 41, 11258-11267. [CrossRef]

83. Yue, W.; Liu, X.; Guo, W.-X.; Gao, E.-Q. Structural diversity and magnetic properties of Co(II)/Mn(II)/Ni(II) coordination polymers constructed from an unsymmetrical tetracarboxylic acid and varying $\mathrm{N}$-donor ligands. CrystEngComm 2018, 20, 4258-4267. [CrossRef]

84. Fiorini, G.; Carrella, L.; Rentschler, E.; Alborés, P. Structural characterization and magnetic property studies of a mixed-valence $\left\{\mathrm{Co}^{\mathrm{III}} \mathrm{Co}^{\mathrm{II}}{ }_{4}\right\}$ complex with a $\mu_{4}$-oxo tetrahedral $\left\{\mathrm{Co}_{4}{ }_{4}\right\}$ motif. Dalton Trans. 2020, 49, 932-940. [CrossRef]

85. Sun, H.; Gao, Q.; Chhiba, S.; Chibueze, O.J.; Li, Y. Tetranuclear zinc and cobalt clusters with dicubane-typetopology: Synthesis, structures, luminescent and magnetic properties. ChemistrySelect 2019, 4, 11015-11018. [CrossRef]

86. Papaefstathiou, G.S.; Escuer, A.; Raptopoulou, C.P.; Terzis, A.; Perlepes, S.P.; Vicente, R. Defective double-cubane, tetranuclear manganese(II) and cobalt(II) complexes with simultaneous $\mu_{1,1}$-Azido and $\mu-\mathrm{O}$ bridges. Eur. J. Inorg. Chem. 2001, 1567-1574. [CrossRef]

87. Zurine, E.; Serna, Z.E.; Urtiaga, M.E.; Barandika, M.G.; Corte’s, R.; Martin, S.; Lezama, L.; Lsabel, M.; Arriortua, M.I.; Rojo, T. Dicubane-like tetrameric cobalt(II)-pseudohalide ferromagnetic clusters. Inorg. Chem. 2002, 40, 4550-4555.

Publisher's Note: MDPI stays neutral with regard to jurisdictional claims in published maps and institutional affiliations. 